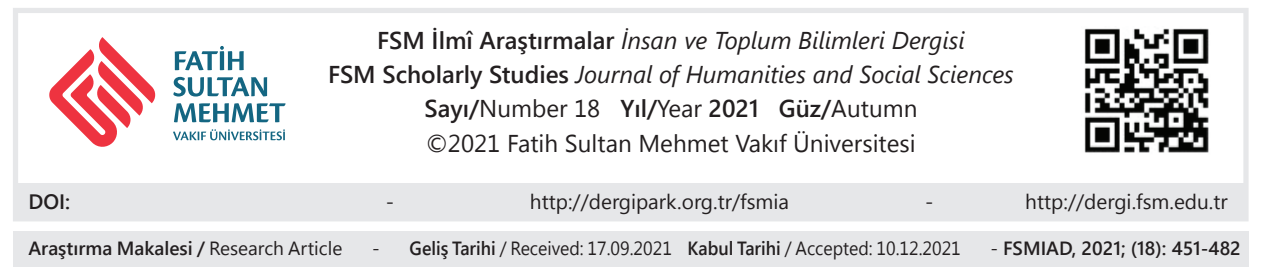

\title{
Ehl-i Sünnet Kelâmcılarına Göre Terâdüf
} Şaban Öztürk*

\section{Öz}

Bu çalışmada terâdüf (eşanlamlılık) konusu, kelâm ilmi -özellikle Ehl-i Sünnet kelâmcıları- açısından ele alınmıştır. Konu, esasen bir dil problemi olması nedeniyle Arap dilcilerinin görüşleri öncelikle ortaya konulmuştur. Bu bağlamda terâdüfün sözlük ve terim anlamı, dilcilerden terâdüf taraftarları ve karşıtlarının görüşleri ve delilleri, terâdüfün ortaya çıkışı, terâdüfü doğuran sebepler, terâdüfün çeşitleri gibi konulara değinilmiştir. Terâdüf konusu, Ehl-i Sünnet kelâm âlimlerinin görüşleri çerçevesinde ve onların temel kelâm kaynaklarına müracaat edilerek değerlendirilmiştir. Söz konusu kelâmcıların terâdüfe yaklaşımları iki açıdan ortaya konulmuştur. Birincisi, bazı Ehl-i Sünnet kelâm âlimleri kronolojik sırayla ele alınarak terâdüf konusundaki görüşleri, müterâdif kabul ettikleri veya etmedikleri kelimeler tespit edilmeye çalışılmış ve bunlarla ilgili yaptıkları açıklamalara yer verilmiştir. İkinci olarak, ulûhiyyet, nübüvvet, âhiret, esmâ ve ahkâm, varlık ve bilgi gibi temel kelâm konularına ilişkin müterâdif oldukları iddia edilen bazı kavramlar ele alınarak aralarındaki farklar ortaya konulmaya çalışılmıştır. Böylece iki ayrı kavramı bir anlamda kabul etmenin anlam kaybına yol açıp açmadığı gösterilmeye çalışılmıştır.

Anahtar Kelimeler: Kelâm, terâdüf, furûk, ulûhiyyet, nübüvvet, âhiret. * Doktora Öğrencisi, İstanbul Üniversitesi Sosyal Bilimler Enstitüsü, İstanbul/Türkiye, saba-
nozturk3@gmail.com, orcid.org/0000-0002-1920-2089. 


\title{
The Subject of Synonymy from the Perspective of Ahl as-Sunnah Kalam Scholars
}

\begin{abstract}
This study discusses the subject of taraduf (synonymy) from the prospect of the science of kalam. First, the views of Arab linguists have been presented as the subject is essentially a linguistic problem. In this perspective, the lexical and term meaning of taraduf, the views and evidence of proponent and disputant linguists for the taraduf subject, the emergence of taraduf, the direct causes of taraduf, and the types of taraduf are mentioned. Then, the subject of taraduf has been evaluated within the framework of the views of Ahl as-Sunnah kalam scholars while referring to their studies. The approaches of the stated scholars to taraduf are examined in two aspects. First, some Ahl as-Sunnah kalam scholars are examined in chronological order by showing their views on taraduf, the words they repeatedly accepted or did not accept, and their explanations about these words. Secondly, the terms from kalam studies claimed to be synonyms, such as divinity, prophecy, the hereafter, names and judgments, and existence and knowledge, have been discussed to reveal their differences. Thus, it has been tried to show whether accepting two different notions as synonym leads to a loss of meaning.
\end{abstract}

Keywords: Kalam, synonymy, distinction, divinity, prophecy, hereafter. 


\section{Giriş}

Kelâm ilminin temel kaynakları, diğer İslâmî ilimlerde olduğu gibi Arapçadır. Ayrıca kelâmın konusu olan inançlarla ilgili kavramların temel kaynakları olan Kur'ân ve hadîslerin dili de Arapçadır. Dolayısıyla Arap dilinde bir olgu olan terâdüf konusu kelâm ilmini de ilgilendirmektedir. Bu sebeple önce terâdüf kelimesinin sözlük ve terim anlamını izah edip lafız-manâ ilişkisiyle ilgili diğer kavramları kısaca açıkladıktan sonra, dilcilerin ve ardından kelâmcıların konuyla ilgili görüşlerini ortaya koymaya çalışacağız.

Kelâmda terâdüf konusunda herhangi bir çalışma yapılmadığı gibi, diğer alanlarda terâdüf konusunda yapılan çalışmalarda da kelâmcıların terâdüf anlayışlarına değinilmemiştir. Dil ve edebiyat dışında yapılan araştırmalarda, genellikle Kur'ân-1 Kerîm’de terâdüf konusuyla alakalı olarak müfessirlerin görüşleri üzerinde durulmuş, bunun dışında usûl-i fikıh âlimlerinin terâdüf ile ilgili görüşlerine yer verilmiş, kısmen de mantıkçıların terâdüfe dair görüşlerinden bahsedilmiştir. Ancak bizim kelâm âlimleri (mütekellim) olarak kabul ettiğimiz Ebû Hâmid el-Gazzâlî, Fahreddîn er-Râzî, Seyfüddîn el-Âmidî, Beyzâvî ve Zemahşerî gibi âlimler, terâdüf konusunda yapılan çalışmaların çoğunda tefsir veya usûl-i fikıh âlimleri olarak zikredilmiştir.

\section{Terâdüf Kavramı}

\subsection{Terâdüfün Sözlük Anlamı}

Terâdüf, sözlükte r-d-f kökünden türemiş olup bu kökten gelen ridf, "bir şeye tabi olan"; "vezir", "kuyruk ve arka", "heybe, çanta", "kralın sağ tarafında oturan kimse", "gece ve gündüz" anlamalarına gelir. Bu kökten türeyen diğer kelimelerden redf, "bir şeye tabi olmak"; redîf ve mürtedif, "bir kimsenin terkisine binen"; ridâfe, "câhiliyye döneminde kralların arkasından gidenler"; rüdâfâ, "bir kimsenin avanesi ve yardımcıları"; irdâf, "bir kimseyi terkisine bindirmek", "tabi olmak"; terâdüf, "bir şeyin başka bir şeyin arkasına binmesi"; "peşpeşe dizilmesi"; mürâdefe, "iki şeyin birbiri ardınca gelmesi"; irtidâf, "birisinin ardindan giderek onu tutmak"; istidrâf, "birinin terkisine binmek istemek" demektir.

1 Halîl b. Ahmed Ferâhîdî, Kitâbu'l- 'Ayn, tah. Abdulhamîd Hindâvî, 1. bs., c. II, Beyrut, Dâru'l-Kütübi'l-İlmiyye, 1424/2003, s. 112-113; Ebu'l-Hüseyn Ahmed b. Fâris b. Zekeriyyâ İbn Fâris, Mu 'cemu Mekâyîsi'l-Luga, tah. Abdüsselâm Muhammed Hârûn, c. II, y.y., Dâru'l-Fikr, t.y., s. 503-504; Ebû Nasr İsmâîl b. Hammâd Cevherî, Tâcu'l-Lüga ve Sihâhu'l-Arabiyye, Kâhire, Dâru'l-Hadîs, 1430/2009, s. 437; Ebu'l-Kâsım Cârullah Muhammed b. Ömer b. Ahmed Zemahşerî, Esâsü'l-Belâğa, 1. bs., c. I, Beyrut, Dâru'l-Kütübi'l-İlmiyye, 1419/1998, s. 348. 
$R$ - $d$ - $f$ kökünden türeyen kelimeler ortak olarak "her ikisi de aynı çizgide olacak şekilde bir şeyin diğer şeyin arkasından gitmesi" "bir şeyin arkasına veya peşine bitişen bir kalabalık veya kütle"3 anlamlarına gelmektedir.

Kur'ân-1 Kerim'de $r$ - $d$-f kökünden türeyen kelimelerden mürdifin 4 "peşpeşe" anlamında olup "meleklerin bölük bölük birbiri ardınca gelmesini" ifade eder. Redife $e^{7}$ kelimesi, "hemen peşinden gelme" anlamındadır. Râdife 9 ise, "ardından gelme" anlamında olup râcife'nin nefha-i ûlâ, râdife'nin de nefha-i sâniye olduğu söylenmiştir. ${ }^{10}$ Yine râcife'nin, zelzeleden sonra gelecek olan kıyâmetin kopuşu olduğu da ifade edilmiştir. ${ }^{11}$

Hadislerde de $r$ - $d$ - $f$ kökünden türeyen çeşitli kelimeler geçmektedir. ${ }^{12} \mathrm{Bu}$ kökten gerek âyetlerde gerekse hadislerde geçen kelimelerin tamamı sözlük anlamında kullanılmışlardır.

\subsection{Terâdüfün Terim Anlamı}

Terâdüfün terim anlamı konusunda âlimler ve araştırmacılar arasında bir ittifak yoktur. Çünkü terâdüfü kabul edenler ve etmeyenler arasındaki görüş ayr1lıkları ve her bir grubtaki âlimlerin bakış açılarındaki farklılıklar tanımlara yansımıştır. ${ }^{13} \mathrm{Bu}$ tanımlardan bazıları şöyledir: Terâdüf, "mefhûm birliğinin olması, zât birliğinin olmaması"dır. "İnsan" ve "beșer" gibi. ${ }^{14}$ Terâdüf, "müfred iki veya

2 Hasan Mustafavî, et-Tahkîk fî Kelimâti 'l-Kur'âni'l-Kerîm, 1. bs., c. IV, Tahran, 1385, s. 114.

3 Muhammed Hasan Hasan Cebel, el-Mu 'cemu'l-İstikâkî el-Muassal li Elfâzi'l-Kur'âni'l-Kerîm, 1. bs., Kahire, Mektebetü'l-Âdâb, 2010, s. 790-91.

4 Enfâl, 8/9.

5 Ebû Zekeriyyâ Yahyâ b. Ziyâd Ferrâ, Me 'ânî'l-Kur'ân, 3. bs., c. I, Beyrut, Âlemü'l-Kütüb, 1403/1983, s. 404.

6 Cebel, el-Mu 'cemu'l-İstikâkî, s. 791; Mustafavî, et-Tahkîk, c. IV, s. 115.

7 Neml, 27/72.

8 Cebel, el-Mu'cemu'l-İstikâkî, s. 791; Mustafavî, et-Tahkîk, c. IV, s. 115.

9 Nâzi'ât, 79/6-7.

10 Ferrâ, Me 'ânî'l-Kur'ân, c. III, s. 231.

11 Cebel, el-Mu'cemu'l-Iştikâkî, s. 791; Mustafavî, et-Tahkîk, c. IV, s. 115.

12 Buhârî, "Hac", 93; "Salât", 12; "Cihâd", 46, 59, 126, 127; "Da'avât", 35; "Megâzî", 37, 49, 77; "Tefsîr”, 3; "Libâs”, 98; “Edeb”, 115; “İsti’zân”, 20; Müslim, "İmân”, 47; "Hacc”, 147; "Cihâd", 116, 120, 131, 132; "Nikâh", 84, 87; "Hayz", 79; "Şi'r'”, 1; Ebû Dâvûd, "Tahâret", 120; "Cihâd", 44, 48; "Menâsik", 56, 63; Nesâî, "Hacc", 79, 228, 229; Tirmizî, "Hacc”, 54; İbn Mâce, "Menâsik", 69, 84; Dârimî, "Vudû"”, 72; "Menâsik", 34, 52, 60.

13 Muhammed b. Abdurrahman Sâlih Şâyi', el-Furûku'l-Lügaviyye ve Eserühâ fì Tefsîri'l-Kur'âni'l-Kerîm, 1. bs., Riyad, 1414/1993, s. 36-37.

14 Eyyûb b. Mûsâ el-Hüseynî el-Kefevî Ebu'l-Bekâ, el-Külliyyât, tah. Adnân Dervîş, Muhammed el-Misrî, 2. bs., Beyrut, 1419/1998, s. 315. 
daha fazla lafzın asıl vaz'itibarıyla bir yönden bir manâya delalet etmesidir."15 Terâdüf, "Muhtelif ve münferid birçok kelimenin, bir müsemmâya veya bir manâya tek bir delaletle delalet etmesi"dir. ${ }^{16}$

Terâdüf, dilbilimcilerin değişik tanımları dikkate alınmak suretiyle genel olarak, "aralarından kök birliği ve fonetik bir yakınlık olmaksızın birden çok lafzın tek bir mana için kullanılmasıdır." ${ }^{17}$ şeklinde tarif edilebilir.

Bazı âlimler de "müterâdif" kelimesini temel alarak tanım yapmışlardır: Müterâdif, "Bir müsemmâ hakkındaki muhtelif lafizlar ve ard arda gelen sigalar"dır. "İcki anlamına gelen el-hamr ve el- 'ukâr kelimeleri gibi. ${ }^{18}$ Müterâdif, "Bir itibarla bir şeye delalet eden müfred lafizlardır."19 Müterâdif, "manâsı bir, isimleri birden çok olan lafizdır. "Aslan" anlamındaki el-leys ve el-esed kelimeleri gibi."20

Terâdüf ve müterâdif kelimelerinin sözlük ve terim anlamları arasında ilişki olduğu açık bir şekilde görülmektedir. Terâdüf kelimesinin sözlükteki, "birinin başka birinin arkasına (terkisine) binmesi” anlamı, bu hakikî anlamdan alınarak mecâzî olarak terim anlamına nakledilmiştir. ${ }^{21}$

Yapılan açıklamalardan anlaşılmaktadır ki, terâdüf veya müterâdif kavramları lafız-manâ ilişkisiyle alakalı kavramlardan biridir. Bu bağlamda kısaca, "iki ve daha fazla kelimenin aynı mânâya gelmesi” anlamındaki terâdüfün lafız-manâ ilişikisindeki yerini anlamak için konuyla alakalı mütebâyin, müşterek, tezâd vb. gibi kavramları kısaca hatırlamakta yarar görüyoruz.

Mütebâyin, bir lafzın bir manâya delalet etmesidir. Eğer iki şey, birbirine ait hiçbir şeyi karşılamıyorsa buna "küllî tebâyün" denilir; "insan ve at" gibi. Eğer bir kısmı karş1liyorlarsa, aralarında “cüz’î tebâyün” var demektir; "hayvan ve beyaz" gibi. ${ }^{22}$

15 Muhammed Ali Tehânevî, Keş̧̧âfu Istılâhâti'l-Fünûn ve'l-Ulûm, tah. Refîk el-Âcem, Ali Dehrûc, 1. bs., Beyrut, 1996, s. 406.

16 Bkz. Hâkim Mâlik Ziyâdî, et-Terâdüffi'l-Luga, Bağdat, 1980, s. 32.

17 Bkz. Mustafa Alvânî, “Arap Dilinde Terâdüf (Eşanlamlılık)”, Cumhuriyet Üniv. İlahiyat Fak. Dergisi, çev. Galip Yavuz, sayı 1, 1996, s. 231.

18 Ebû Hâmid Gazzâlî, el-Mustasfâ min 'İlmi'l-Usûl, tah. Hamza b. Züheyr Hâfız, y.y., t.y., s. 95-96; a.mlf., Mihekkü'n-Nazar, tah. Refîk el'Acem, Beyrut, t.y., s. 75.

19 Celâlüddîn Suyûtî, el-Müzhir fì 'Ulûmi'l-Luga ve Envâ'ihâ, tah. Muhammed Ahmed Câd el-Mevlâ, 4. bs., c. I, Kahire, 1958, s. 402; krş. Bedrüddîn Muhammed b. Abdullah Zerkeşî, el-Bahru'l-Muhît fì Usûli'l-Fıkh, tah. Abdulkâdir Abdullah el-'Ânî, 2. bs., c. II, Kuveyt, 1413/1992, s. 105.

20 Ali b. Muhammed es-Seyyid eş-Şerîf Cürcânî, Mu'cemu't-Ta 'rîfât, tah. Muhammed Siddîk el-Minşâvî, Kahire, Dâru'l-Fazîle, t.y., s. 167.

21 Ziyâdî, et-Terâdüf, s. 32-33.

22 Gazzâlî, el-Mustasfâ, s. 96; Seyfüddîn Âmidî, el-Mübîn fỉ Şerhi Me ânî Elfâzi'l-Hukemâ' ve'l-Mütekellimîn, tah. Hasan Mahmûd eş-Şâfi'î, Kahire, 1413/1993, s. 72; Cür- 
Müşterek, bir lafzın bir itibarla olmaksızın birden fazla şeye delalet etmesidir. Örneğin 'ayn (göz) kelimesi gibi. Zira 'ayn lafzı, "insanın görme organı”, "terazinin kefesi", "suyun çıktığı kaynak" gibi şeyler için kullanılır. ${ }^{23}$

Mütevâtı', sayıca birbirinden farklı, fakat ismin konulduğu manâda müttefik olan lafızdır. Zeyd, Ömer, Bekir ve Hâlid için kullanılan "recül/erkek" ismi; gök, yer ve insan için kullanılan "cisim" ismi gibi. ${ }^{24}$

Tezâd, bir lafzın birbirine zıt iki manâya delâlet etmesidir. Hem gece hem gündüz için kullanılan es-sarîm (geçen) kelimesi gibi. ${ }^{25}$

Bu kavramlardan her biri lafız manâ ilişkisinin farklı boyutlarıyla ilgilidir. Bizim araştırmamız terâdüf kavramı çerçevesinde olacaktır. Bu nedenle önce Arap dil âlimlerinin görüşlerini k1saca ortaya koyduktan sonra, asıl konumuz olan kelâmcıların terâdüfle ilgili görüş ve yaklaşımlarını ortaya koymaya çalışacağız.

\section{Arap Dil Bilginlerine Göre Terâdüf}

\subsection{Terâdüfü Kabul Edenler ve Etmeyenler}

Araştırmacılar, Arap dili ve edebiyatı tarihinde terâdüf konusunda görüş bildiren gerek eski ve gerekse yeni dilcileri, "terâdüfü kabul edenler" ve "terâdüfü kabul etmeyenler" olarak iki ana gruba ayırmışlardır:

\subsubsection{Terâdüfü Kabul Eden Dilciler}

1) Sîbeveyh (ö. 180/798) ${ }^{26}$

2) Kutrub (ö. 210/825) ${ }^{27}$

3) Ebû Zeyd el-Ensârî (ö. 215/830)28

cânî, et-Ta 'rîfât, s. 167-280; Münâvî, et-Tevkîf 'alâ Mühimmâti't-Te 'ârîf, s. 90; Ömer Ali Makûşî, “et-Terâdüf ve'l-İștirâku'l-Lafzî ve't-Tezâd - Dirâse fî Ârâi'l-Lügaviyyîn ve Esbâbi'n-Nuşû'-", Havliyyetü Külliyyeti'd-Dirâseti'l-İslâmiyye ve'l-'Arabiyye li'l-Benât, cilt III, sayı 3, İskenderiyye, s. 842.

23 Ebû Bişr Amr b. Osmân b. Kanber el-Hârisî Sîbeveyh, el-Kitâb (Kitâbu Sîbeveyh), tah. Abdüsselâm Muhammed Hârûn, 3. bs., c. I, Kahire, 1408/1988, s. 24; Gazzâlî, el-Mustasfâ, s. 97; Âmidî, el-Mübîn, s. 71; Suyûtî, el-Müzhir, c. I, s. 369.

24 Gazzâlî, el-Mustasfâ, s. 96; Âmidî, el-Mübîn, s. 70-71; Cürcânî, et-Ta 'rîfât, s. 167-280.

25 Muhammed b. el-Kâsım İbnü'l-Enbârî, Kitâbu'l-Ezdâd, tah. Muhammed Ebu'l-Fazl İbrâhîm, Beyrut, el-Mektebetü'l-Asriyye, 1407/1987, s. 8; Makûşî, “et-Terâdüf ve'l-Iștirâku'l-Lafzî ve’t-Tezâd - Dirâse fî̀ Ârâi'l-Lügaviyyîn ve Esbâbi'n-Nuşû'-”, s. 842.

26 Bkz. Sîbeveyh, el-Kitâb, c. I, s. 24.

27 Bkz. Ebû Ali Muhammed b. el-Müstenîr Kutrub, Kitâbu'l-Ezdâd, tah. Hannâ Haddâd, Riyad, 1405/1984, s. 69-70.

28 Bkz. Şâyi', el-Furûk, s. 46-47. 
4) Esma‘î (ö. 216/831) ${ }^{29}$

5) Müberred (ö. 286/900) $)^{30}$

6) Abdurrahman el-Hemedânî (ö. 320/932)

7) İbn Hâleveyh el-Hemedânî (ö. 370/980)32

8) Rummânî (ö. 384/994) ${ }^{33}$

9) İbn Cinnî (ö. 392/100234

10) Se'âlibî (ö. 429/1038) 35

11) İbn Sîde (ö. 458/1066) ${ }^{36}$

12) İbnü'l-Hâcib (ö. 646/1249) $)^{37}$

13) Fîrûzâbâdî (ö. 817/1415)

14) İbn Mâlik et-Tâi (ö. 672/1274) $)^{39}$

29 Bkz. İbn Fâris, es-Sâhibî, s. 21; İbnü’n-Nedîm, el-Fihrist, c. I, s. 157; Suyûtî, el-Müzhir, c. I, s. 325.

30 Bkz. Ebu'l-Abbâs b. Yezîd Müberred, Mâ İttefeka Lafzuhu ve İhtelefe Ma 'nâhu mine'l-Kur'âni'l-Mecîd, tah. Ahmed Muhammed Süleyman Ebû Ra'd, 1. bs., Kuveyt, Vezâret'l-Evkaf ve'ş-Şu'ûnu'l-İslâmiyye, 1409/1988, s. 47; Ebû Hilâl el-Askerî, el-Furûku'l-Lügaviyye, tah. Muhammed İbrâhîm Selîm, Kahire, t.y., s. 11; İbnü’n-Nedîm, el-Fihrist, c. I, s. 172.

31 Bkz. Mârûn Abbûd, Edebü'l-Arab, Kahire, Müessesetü Hindâvî, 2014, s. 197; Şâyi`, el-Furûk, s. 54.

32 Bkz. Şâyi', el-Furûk, s. 47; krş. Suyûtî, el-Müzhir, c. I, s. 405.

33 Bkz. Ebu'l-Hasan Ali b. İsâ Rummânî, el-Elfâzu'l-Müterâdifetü'l-Mütekâribetü'l-Ma 'nâ, tah. Fethullah Sâlih Ali el-Misrî, 1. bs., y.y., 1407/1987, s. 49-85; Ebu'l-Hasan Ali b. İsâ b. Ali Rummânî, Tefsîru Ebi'l-Hasan er-Rummânî, (Mevsû'atu Tefâsiri'l-Mu'tezile), cem ve tah. Hidr Muhammed Nebhâ, c. V, Lübnan, 2009, s. 23, 39, 85, 130, 250; krş. Ali b. Mûsâ b. Ca'fer İbn Tâvûs, Sa 'du's-Su 'ûd li'n-Nufûs, tah. Fâris Tebrîzân el-Hassûn, İran, 1379, s. 487-88.

34 Ebu'l-Feth Osman İbn Cinnî, el-Hasâis, tah. Muhammed Ali en-Neccâr, 3. bs., c. II, y.y., el-Hey'etü'l-Misriyyeti'l-Âmme li'l-Kitâb, 1988, s. 115, 372-374, 468; Müneccid, et-Terâdüf, s. 58, 69; Şâyi', el-Furûk, s. 50-51.

35 Bkz. Ebû Mansûr Abdulmelik b. Muhammed b. İsmâîl Se 'âlibî, Flkhu'l-Luğa ve Esrâru'l- 'Arabiyye, tah. Yâsîn el-Eyyûbî, 2. bs., Beyrut, 1420/2000, s. 43-352; krş. s. 59; Subhî es-Sâlih, Dirâsât fì Flkhi'l-Lŭ̆a, s. 298.

36 Bkz. Ebu'l-Hasan Ali b. İsmâîl İbn Sîde, el-Muhassas, 1. bs., Misır, 1320h., c. XIII, s. 260.

37 Bkz. Ebû Amr Osman b. Ömer b. Ebî Bekr İbnü'l-Hâcib, Müntehâ 'l-Vusûl ve'l-Emel fî̀ 'İlmeyi'l-Usûl ve'l-Cedel, 1. bs., Misır, 1326h., s. 13-14.

38 Bkz. Mecdüddîn Muhammed b. Ya 'kûb Fîrûzâbâdî, Besâiru Zevî't-Temyîz fì Letâfi Kitâbi'lAzîz, tah. Muhammed Ali en-Neccâr, 3. bs., c. II, Kahire, 1416/1996, s. 227, 544-546; c. III, s. 300; krş. Şâyi', el-Furûk, s. 51-52.

39 Bkz. Muhammedb.Abdullah İbn Mâlik et-Tâî,Kitâbu'l-Elfâzi'l-Muhatelifefi 'l-Me 'ânî'l-Mu'telife, tah. Necât Hasan Abdullah Nevlî, Mekke, Câmi'atu Ümmi'l-Kurâ, t.y., s. 21. 


\subsubsection{Terâdüfü Kabul Etmeyen Dilciler}

1) İbnü'l-A'râbî (ö. 231/844) ${ }^{40}$

2) İbn Kuteybe (ö. 276/889)41

3) Sa'leb (ö. 291/904) $)^{42}$

4) İbnü'l-Enbârî (ö. 328/940) $)^{43}$

5) İbn Dürüsteveyh (ö. 347/958) $)^{44}$

6) Ebû Ali el-Fârisî (ö. 377/987) (5 $^{45}$

7) İbn Fâris (ö. 395/1004) ${ }^{46}$

8) Ebû Hilâl el-Askerî (ö. 400/1009) $)^{47}$

Eski ve yeni âlimlerin bir kısmı, terâdüfü kabul etmeyenlerin azınlık (şâz) olduklarını ve terâdüfü kabul edenlerin, ulemânın cumhûru ${ }^{48}$ olduklarını ifade ederek, bunu dilde terâdüfün varlığına delil olarak getirmektedirler.

\subsection{Terâdüf Çeşitleri}

Terâdüfü kabul edenler terâdüfü çeşitli kısımlara ayırmışlardır:

1) Tam (kâmil) terâdüf: Buna "temâsül”" (birbirine benzeme) de denilmiştir. Tam terâdüf, iki lafız birbirine tam olarak mutabık oldukları ve mütekellimin bu iki lafız arasında hiçbir fark hissetmediği ve birini diğerinin yerine rahat

40 İbnü'l-Enbârî, Kitâbu'l-Ezdâd, s. 7; Suyûtî, el-Müzhir, c. I, s. 399-400; Müneccid, et-Terâdüf, s. 37-38; Ziyâdî, et-Terâdüf, s. 198; Şâyi`, el-Furûk, s. 91-92.

41 Bkz. Ebû Muhammed Abdullah b. Müslim İbn Kuteybe, Edebü'l-Kâtib, tah. Ali Fâ‘ûr, y.y., t.y., s. 23-29; krş. Ziyâdî, et-Terâdüf, s. 222.

42 Bkz. İbn Fâris, es-Sâhibî, s. 115; Ali b. Abdulkâfî Sübkî, el-İbhâc fî Şerhi'l-Minhâc, tah. Şa ‘bân Muhammed İsmâîl, c. I, Kahire, 1401/1981, s. 240; Suyûtî, el-Müzhir, c. I, s. 403-404; Ziyâdî, et-Terâdüf, s. 198; Şâyi‘, el-Furûk, s. 90.

43 Bkz. İbnü'l-Enbârî, Kitâbu'l-Ezdâd, s. 7-8; Suyûtî, el-Müzhir, c. I, s. 400-401; Müneccid, et-Terâdüf, s. 40; Ziyâdî, et-Terâdüf, s. 199.

44 Bkz. Ebû Muhammed Abdullah b. Ca'fer İbn Dürüsteveyh, Tashîhu'l-Fasîh ve Şerhihi, tah. Meuhammed Bedevî el-Mahtûn, Kahire, 1425/2004, s. 70-1; Ebû Hilâl el-Askerî, el-Furûk, s. 12-13; Şâyi“, el-Furûk, s. 94; Ziyâdî, et-Terâdüf, s. 200-201.

45 Bkz. Şâyi', el-Furûk, s. 55; krş. Suyûtî, el-Müzhir, c. I, s. 405.

46 Bkz. İbn Fâris, es-Sâhibî, s. 21, 114-16; Suyûtî, el-Müzhir, c. I, s. 404; Şâyi`, el-Furûk, s. 89-90.

47 Bkz. Ebû Hilâl el-Askerî, el-Furûk, s. 21-22, 25-28; Ebû Hilâl el-Askerî, Kitâbu's-Sinâ 'ateyn: el-Kitâbe ve'ş-Şi 'r, Kitâbu's-Sinâ'ateyn: el-Kitâbe ve'ş-Şi 'r, tah. Ali Muhammed el-Becâvî, Muhammed Ebu'l-Fazl İbrâhîm, 1371/1952, s. 6, 158, 373; Şâyi‘, el-Furûk, s. 88.

48 Seyfüddîn Âmidî, el-İhkâm fî Usûli'l-Ahkâm, tah. Abdurrezzâk Afîfî, 1. bs., Riyad, 1424/2003, s. 41; Şâyi', el-Furûk, s. 136, 139; Ziyâdî, et-Terâdüf, s. 219-220. 
ve özgür bir şekilde kullandığ̣ zaman olur. Dolayısıyla terâdüfü kabul eden dilciler, müterâdif olarak kabul ettikleri kelimeler arasında hiçbir anlam fark1 görmemişlerdir.

2) Şibhü 't-terâdüf: Buna "tekârüb" (birbirine yakın olma) veya "tedâhül (içiçe geçme) de denilir. Şibhü’t-terâdüf, iki lafız -uzman olmayan kimselerin- birbirinden ayırmalarını zorlaştıracak şekilde son derece birbirlerine yakın (mütekârib) oldukları zaman olur. Bu yüzden çoğu o iki lafzı aralarındaki farkı dikkate almadan kullanmaktadır. Arapçada bunun örneği, Kur'ân-1 Kerîm'de de geçen ve hepsi de "yıl" anlamına gelen 'âmm, sene ve havl lafizlarıdır.

3) Semantik yakınlık: Bu, manâlar birbirine yakın (mütekârib) olduğu, fakat iki lafız arasında çok küçük bir farklılık olduğu zaman olur. Arapçada bunun örneği, Kur'ân-1 Kerîm'de de geçen ve ikisi de "rüya" anlamına gelen, hulm ve rü'yâ lafizlarıdır.

4) Umumîlikte farklılık: Bu terâdüf, kelimenin manâsının husûsî manâdan umûmî manâya intikal etmesiyle gerçekleşir. "Bağış/ihsân" anlamına gelen en-Nec'a, el-menîha ve el-văgy gibi.

5) Husûsîlikte yakınlık: Bu, kelimenin manâsının umûmî manâdan husûsî manâya intikal etmesiyle gerçekleşir. el-Hacc ve es-sebt gibi.

6) Kuvvette farklılık: Müterâdif iki kelime arasında kuvvet ve vurgu farkının olmasıdır. Her ikisi de "tuzak" anlamına gelen keyd ve mekr gibi.

7) İmâda farklılık: Müterâdif kabul edilen iki kelimenin farklı imâlarda bulunması suretiyle gerçekleşir. el-Bess ve el-hüzn gibi. ${ }^{49}$

\section{Ehl-i Sünnet Kelâmcılarının Terâdüf ile İlgili Görüşleri}

\subsection{Ehl-i Sünnet Kelâmcılarında Terâdüf Kavramı}

Kelâmcılar, fikirlerini ifade edecekleri bir araç ve inançlarını yayacakları bir vasıta olduğu için dile çok önem vermişlerdir. Onların dile önem vermelerinin diğer bir sebebi de, ana kaynakları olan Kur'ân ve hadisi anlama ihtiyaçlarıdır. ${ }^{50}$ Câhız, kelâmcı için dilin önemine şöyle dikkat çekmiştir:

"Arapların meselleri, iştikâkları ve binaları vardır. Kelâmın konuluşu, onlara göre kendi maksatlarına ve irâdelerine delalet eder. Bu lafızların baş-

49 Ahmed Muhtâr Ömer, 'İlmu'd-Dilâle, 5. bs., Kahire, 'Âlemü'l-Kütüb, 1998, s. 220-21; Ziyâdî, et-Terâdüf, s. 70; Farid Haidar - Edi Kurniawan, “et-Tahlîlü'd-Dilâlî 'ani’t-Terdâdüf fi'l-Âyâti'l-Kur'âniyye Sûreti Yûsuf”, An-Nas: Jurnal Humaniora, vol. 2, num. 1, September 2017, s. 5-8.

50 Ali Bû Mulhim, el-Menâhi'l-Felsefiyye 'inde'l-Câhız, 2. bs., Beyrut, 1988, s. 223. 
ka konuluşları ve dolayısıyla başka delaletleri de vardır. Bunları bilmeyen kimse Kitâb ve Sünnet'in, şâhidin ve meselin te'vîlinde hataya düşer." ${ }^{1}$

Kelâma dair eserleri incelediğimizde kelâmcıların bu konuyu dil bilimciler, usûlcüler ve müfessirler gibi, geniş anlamda ele almadıklarını, dilde terâdüfün olup olmadığ konusunu tartışmadıklarını görüyoruz. Fakat iki kelimenin müterâdif (eş anlamlı) olduğunu belirtmek için genellikle "terâdüf", "müterâdif" veya "mürâdif" gibi kavramları kullanmışlar, fakat bu kavramların tanımlarını yapmamışlardır. Bazen de müterâdif veya terâdüf kelimelerini hiç kullanmadan terâdüfü başka kelimelerle ve ifadelerle dile getirmişlerdir. Meselâ İmâm Mâtürîdî, "imân ve islâm" kavramlarının müterâdif olduğunu "vâhid" (bir, aynı) kelimesini kullanarak şöyle ifade ediyor: 'Bunda (bu âyette), imân ve islâm'ın bir/ aynı (manâda) olduklarına delalet vardır." ${ }^{2}$ Yine İmâm Mâtüridî başka bir yerde ise, ma 'nâ kelimesini ekleyerek konuyu daha vurgulu bir şekilde ifade etmiştir: “Sonra O'nun ... sözü, islâm ve imânın hakikatte bir olduklarına delalet eder. Her ne kadar bu ikisi bir yönden muhtelif iseler de, hakiki manâda birdirler." 53

Bazı kelâmcılar ise, müterâdif lafzına ilaveten dilcilerin kullandıkları 1st1lah ve tabirleri de kullanmaktadırlar. Meselâ, İbn Hazm (ö. 456/1064), "nefs" ve "rûh"un müterâdif olduğunu vurgulu bir şekilde şöyle ifade ediyor: "Bizde böyle söylüyoruz: Nefs ve rûh, bir müsemmâya ait ve her ikisi de bir manâda olan müterâdif iki isimdirler." 54 İbn Hazm, başka bir yerde şöyle diyor: "Başkaları şu görüştedir: İmân ve islâm, bir manâya gelen müterâdif iki lafizdır." ${ }^{55}$

Verdiğimiz bu bilgilerden anlaşılacağı üzere kelâmcıların, bazen yukarıdaki kavram veya ifadelerden hiçbirini kullanmaksızın bazı kavramları müterâdif kabul ettikleri bağlamdan anlaşılmaktadır.

Terâdüf konusunda daha önce görüşlerini aktardığımız dilcilerin mezhebî durumlarını incelediğimizde, terâdüfü kabul etmeyenlerden Ebû Ali el-Fârisî’nin Mu'tezilî, İbn Fâris'in ise Şiî olduğu tartışmalıdır. Geriye kalan âlimlerin çoğunluğu Ehl-i Sünnet'e mensupturlar.

51 Amr b. Bahr Câhı, Kitâbu'l-Hayevân, tah. Abdüsselâm Muhammed Hârûn, 2. bs., c. I, y.y., 1384/1965, s. 153-54.

52 Ebû Mansûr Muhammed b. Muhammed Mâtürîdî, Te'vîlâtu'l-Kur'ân, c. XXI, İstanbul, Dâru'l-Mîzân, 2007, s. 54.

53 Mâtürîdî, Te'vîlâtu'l-Kur'ân, c. XXI, s. 346.

54 Ebû Muhammed Ali b. Ahmed İbn Hazm, el-Fasl fi'l-Milel ve'l-Ehvâ've'n-Nihal, tah. Muhammed İbrahim Nasr, Abdurrahman Umeyre, 2. bs., c. V, Beyrut, 1416/1996, s. 202.

55 İbn Hazm, el-Fasl, c. III, s. 269. 
Terâdüfü kabul eden dilcilere baktığmızda ise, Kutrub ve Rummânî’nin Mu'tezile mezhebine mensup olduklarını görüyoruz. Bunların dışında Ebû Zeyd el-Ensârî’nin Kaderiyye'ye, İbn Hâleveyh el-Hemedânî’nin ise Şîa'ya mensubiyeti tartışmalıdır. Geriye kalan dil bilginlerinin hemen hepsi Ehl-i Sünnet'e mensupturlar.

Bu değerlendirme bize gösteriyor ki, mezhep mensubiyetinin terâdüfü kabul edip etmeme konusunda herhangi bir etkisi olmadığı gibi, terâdüfü kabul edip etmeme konusundaki tavır da mezhepleşmede etkili olmuş değildir.

\subsection{Ehl-i Sünnet Kelâmcılarının Terâdüf Konusundaki Görüşleri}

Burada Ehl-i Sünnet'in meşhur kelamcılarının terâdüf konusundaki görüşleri örnekler verilerek açıklanmaya çalışılacaktır.

\subsubsection{Ebû Hanîfe (ö. 150/767)}

Ebû Hanîfe'nin, kendi eserlerini veya ondan nakilde bulunan âlimlerin eserlerini incelediğimizde onun, "Tasdîk, Ma'rifet, İkrâr, İslâm ve Yakîn" "K6, "Küfür-Şirk" "Ir "Irâde-Meşîet" karşın Ali el-Kârî (ö. 1014/1065), Ebû Hanife'nin resul ve nebî kelimelerini müterâdif (eş anlamlı) olarak kullandığını ifade etmiştir. ${ }^{59}$ Yine Kemâlüddîn elBeyâzî (ö. 1094/1686) de Ebû Hanîfe'nin rusul (elçiler) ile enbiyâ (nebîler) kelimelerini müterâdif kabul ettiğini nakletmiştir. ${ }^{60}$ Görüldüğü üzere Ebû Hanîfe, bazı kelimeler arasında terâdüf bulunduğunu kabul ederken, bazıları arasında fark gözetmiştir.

\subsubsection{Eş'arî (ö. 324/935-36)}

İmâm Eş‘arî’nin kitaplarını ve ondan yapılan nakilleri incelediğimizde bazen kelimeler arasında fark gözettiğini, bazen ise bazı kelimeleri eş anlamlı kabul ettiğini görüyoruz. Tespitlerimize göre onun aralarında fark gözettiği ke-

56 Ebû Hanife, el-'Âlim ve'l-Müte 'allim, tah. Muhammed Zâhid el-Kevserî, y.y., 1368h., s. 14; Cürcânî, et-Ta 'rîfât, s. 23.

57 İbn Hazm, el-Fasl, c. III, s. 264.

58 Kemâlüddîn b. Ebî Şerîf İbnü'l-Hümâm, Kitâbu'l-Müsâmera fî Şerhi'l-Müsâyera, 2. bs., c. II, Misir, 1347h., s. 8.

59 Ali b. Sultân Muhammed Ali el-Kârî, Minehu'r-Ravzi'l-Ezher fí Şerhi'l-Fıkhi'l-Ekber, 1. bs., Beyrut, 1419/1998, s. 55.

60 Kemâlüddîn Ahmed b. Hasan Beyâzîzâde, İşârâtu'l-Merâm min İbârâti'l-İmâm Ebî Hanîfe en-Nu'mân, tah. Ahmed Ferîd el-Mezîdî, Beyrut, 1428/2007, s. 45. 
lime ve kavramlara şu örnekleri verebiliriz: "Halk-Kesb" "İ1 , În-İslâm"62 "Nebî-Resûl." ${ }^{63}$ Ancak İbn Fûrek' in verdiği bilgilere göre Eş“arî çok sayıda kelimeyi eş anlamlı kabul etmiştir. Onun, aralarında fark gözetmediği ve hepsinin birbirine yakın anlamda (mütekârib) olduklarını söylediğ $i^{64}$ kelime ve kavramlardan bazıları şöyledir: "İlim-Ma 'rifet", "İlim, Yakîn, Fehm, Fıtnat, Dirâyet, Akıl, Fıkh", "Muhdes, İhdâs, Hudûs, Hâdis, Hadîs, Hades, Fi'l, Mef'ûl, Îcâd, Mûced, İbdầ", Mubda', İhtirâ', Muhtera', Tekvîn, Mükevven, Halk, Mahlûk", "Te'lîf, İctimâ", Mümâsse, Mücâvere, Iltizâk, İttisâl", "Iftirâk, Tebâyün, Tebâ 'ud", "Cisim, Cüz', Musavver, Müellef, Mürekkeb, Mümâss, Müctemi', Mücâvir", "Vasf-Sifat", "Kâdir, Kâvî, Kudret, Kuvvet, Kudret, İstitâ'at", "Bedî‘,Mubdi', Mübdi', Muhdis, Münşi', Hâlık, Fâil, Müdebbir, Sâni ', 'Âmil, Bâri', Dâri”"65 gibi. Eş'arî’nin, “islâm ve imân" kelimelerini müterâdif kabul etmediği görülse de, onun çok sayıdaki itikâdî kelimeyi müterâdif kabul ettiği anlaşılmaktadır.

\subsubsection{Mâtürîdî (ö. 333/944)}

İmâm Mâtürîdî, eserlerinde terâdüf lafzını zikrederek konuyu tartışmış değildir. Bu yüzden genelde kelâmda müterâdif kabul edilen kelime ve kavramlara nasıl yaklaştığını onun eserlerinde araştırmak suretiyle terâdüf konusuna nasıl yaklaştı̆̆ını anlamaya çalışacağız. Matürîdî’nin müterâdif kabul ettiği bellibaş11 kelime ve kavramlar şunlardır: "Rahmân-Rahîm"; "Irş̧âd-Hidâyet"; "Tesviye, Halk, Kazâ, İbdâ'; "Imân-Tasdîk"; "Neb̂̂-Resûl"; "Hâlık-Bâri"”66; "Imânİslâm" ${ }^{67}$ gibi.

Mâtürîdî’nin müterâdif olduklarını kabul edip açıkladığı bu kavramlar, onun bazı itikâdî kavramları müterâdif kabul ettiğini göstermektedir. Ancak burada Mâtürî̀î'nin açıklama tarzıyla ilgili iki hususa işaret etmek gerekir. Birincisi, Mâtürîdî'nin terâdüf ve müterâdif kavramlarını veya bu anlama gelecek bir ibareyi kullanmamasıdır. İkinci husus ise, kendi tabiriyle "vâhid/bir" (aynı) kabul

61 Ebû Bekr Ahmed b. el-Hüseyin Beyhakî, el-Kazâ ve'l-Kader ve'r-Red 'alâ men Yahteccü bi'l-Kader, tah. Ebu'l-Fidâ el-Eserî, Beyrut, 1409/1989, s. 69.

62 Ebu'l-Hasan Ali b. İsmail b. Abdullah Eş'arî, el-İbâne 'an Usûli'd-Diyâne, Beyrut, Dâru İbn Zeydûn, t.y., s. 10.

63 Muhammed b. el-Hasan İbn Fûrek, Makâlâtu'ş-Şeyh Ebi'l-Hasan el-Eş 'arî, tah. Ahmed Abdurrahîm es-Sâyih, Kahire, 1425/2005, s. 180.

64 İbn Fûrek, Makâlât, s. 52.

65 İbn Fûrek, a.g.e., s. 6, 26, 27, 28, 38, 45, 49, 109.

66 Mâtürîdî, Te'vîlâtu'l-Kur'ân, c. I, s. 15-16, 21, 70-71; c. IV, s. 225; c. IX, s. 195-96; c. XV, s. 98-99.

67 Ebû Mansûr Muhammed b. Muhammed Mâtürîdî, Kitâbu't-Tevhîd, tah. Bekir Topaloğlu, Muhammed Aruçi, Beyrut, Dar Sader, t.y., s. 394. 
ettiği her iki kavramı, farklı ibare ve tanımlamalarla izah etmesi ve sonunda bu ikisinin "bir" olduğunu ifade etmesidir. Sonuç olarak Mâtürîdî’nin "terâdüf” konusunda herhangi bir açıklamaya gitmeden, eserlerinde bazı kavramları müterâdif kabul etmiştir.

\subsubsection{Bâkıllânî (ö. 403/1013)}

Kâdî Ebû Bekr el-Bakıllânî’nin eserlerini incelediğimizde, onun bazı kelimeleri müterâdif kabul ettiğini, bazı kelimeleri -özellikle Kur'ân kavramlarını-müterâdif kabul etmediğini görüyoruz. Onun, müeterâdif kabul ettiği bazı kelimeler: "İlim-Ma 'rifet"; "Irâde, Meşîet, İhtiyâr, Rlzâ ve Muhabbet"; "İsim-Müsemmâ"; "Imâm-Emîr"68; "Nazar-Fikir"69; "Iman-İslâm""70 gibi.

İsmi, terâdüfü kabul edenler arasında sayılan ${ }^{71}$ Bâk1llânî'nin, Kur'ân-1 Kerim söz konusu olduğunda terâdüfü kabul etmediğini, İslâmî ilimlerde ise bazı kavramlarda kabul ettiğini, bazılarında kabul etmediğini görüyoruz.

\subsubsection{Cüveynî (ö. 478/1085)}

Cüveynî de, bazı itikâdî kavramların müterâdif olduklarını söylemiştir: "Rahmân-Rahîm"'?2; "İmân-İslâm" "73; "Şey-Mevcûd" gibi.

\subsubsection{Ebu'l-Yüsr el-Pezdevî (ö. 493/1100)}

Pezdevî’nin müterâdif olmadıklarını söylediği ve aralarındaki farkları açıkladığı bazı kelimeler şunlardır: "Neb̂̂-Resûl”; "İsim, Müsemmâ, Tesmiye"; "Tekvîn-Mükevven"; "İmân-İslâm"75 gibi.

68 Kâdî Ebû Bekr Muhammed b. Tayyib Bâkıllânî, el-İnsâf fî mâ Yecibu İ'tikâduhu ve lâ Yecûzü'l-Cehlü bihi, tah. Muhammed Zâhid el-Kevserî, 2. bs., Kahire, 1421/2000, s. 13, 43, 57-58, 61.

69 Ali b. Muhammed es-Seyyid eş-Şerîf Cürcânî, Şerhu'l-Mevâkıf, çev. Ömer Türker, c. I, İstanbul, T.C. Türkiye Yazma Eserler Kurumu Başkanlığı, 2015, s. 281.

70 Kâdî Ebû Bekr Muhammed b. Tayyib Bâkıllânî, Kitâbu Temhîdi'l-Evâil ve Talhîsi'd-Delâil, tah. İmâduddîn Ahmed Haydar, 1. bs., Beyrut, 1407/1987, s. 390-92; krş. Bâkıllânî, el-İnsâf, s. 56 .

71 Ziyâdî, et-Terâdüf, s. 220.

72 İmâmu'l-Haremeyn Abdulmelik b. Abdullah Cüveynî, Kitâbu'l-İrşâd ilâ Kavâtı 'il-Edille fì Usûli'l-I'tikâd, tah. Ahmed Abdurrahîm es-Sâyih, Kahire, 1430/2009, s. 128.

73 İmâmu'l-Haremeyn Abdulmelik b. Abdullah Cüveynî, el-'Akîdetü'n-Nizâmiyye fi'l-Erkâni'l-İslâmiyye, tah. Muhammed Zâhid el-Kevserî, Kahire, 1412/1992, s. 87.

74 İmâmu'l-Haremeyn Abdulmelik b. Abdullah Cüveynî, eş-Şâmil fî̀ Usûli'd-Dîn, tah. Ali Sami en-Neşşâr ve dğr., İskenderiyye, 1969, s. 124.

75 Ebü'l-Yüsr Muhammed Pezdevî, Usûlu'd-Dîn, tah. Hans Peter Linss, Kahire, 1424/2003, s. 76, 93, 157, 228, 229. 


\subsubsection{Gazzâlî (ö. 505/1111)}

Gazzâlî, terâdüf kavramı üzerinde en genişs şekilde duran ender kelâmcilardandır. O, el-Maksadu'l-Esnâ isimli eserinde “isim, müsemmâ ve tesmiye"nin birbirinin aynı olup olmadıkları tartışması bağlamında "terâdüf' konusu üzerinde geniş bir şekilde durmaktadır. Gazzâlî, "isim, tesmiye, müsemmî ve müsemmầ"nın müterâdif olmadıklarını "hareket, tahrîk, muharrik ve muharrek" kelimelerini örnekleyerek açıklamaya başlamaktadır. Ona göre bu dört isim birbirinden farklı anlamlara gelmektedir. Hareket, "bir mekândan başka bir mekâna intikal etmeye", tahrîk, "hareketin meydana gelişine", muharrik, "hareketin fâiline" ve muharrek "bir fâilden sâdır olan hareketin kendisinde meydana geldiği şeye" delalet eder. ${ }^{76}$

Gazzâlî, isim-müsemmâ meselesinden sonra el-esmâu'l-hüsnâ'nın da tek bir manâya delalet eden müterâdif olmasının mümkün olmadığını, bunların her birinin farklı anlamları bulunduğunu izah etmektedir. Ona göre eğer iki isim "doksan dokuz isim" kapsamında ise bunların müterâdif olamları son derece uzak bir ihtimaldir. Çünkü isimle, harfleri değil bilakis manâları kastedilir. Müterâdif isimlerin sadece harfleri değişiktir. Çünkü bu isimlerin fazileti, altlarında bulunan manâlar sebebiyledir. Bu sebeple isimler manâdan soyutlandığ zaman geriye sadece lafizlar kalır. ${ }^{77}$

Gazzâlî, Allâh Teâlâ'nın "Ganî-Melik"; "Alîm-Habîr"; "Celîl, Kebîr, Azîm: Celîl, Kebîr ve Azîm"; "Ekber-A 'zam"; "Hâlık, Bâri', Musavvir" sinda fark olduğunu söylemiştir.

Gördülügü üzere bazı kelime ve kavramlarda terâdüf olabileceğini kabul eden Gazzâlî, el-Esmâu'l-Hüsnâ içinde müterâdif isimler olabileceğini kesin bir şekilde reddetmektedir.

\subsubsection{Ebu'l-Mu'în en-Nesefî (ö. 508/1115)}

Ebu'l-Mu'în en-Nesefî de genelde kelâmcilar tarafindan kabul edilen kavramları müterâdif olarak kabul etmiştir: "Nefs, Zât, Mevcûd"; "İsim-Müsemmâa"79; "İmân-Tasdîk" "' "İmân-İslâm" gibi.

76 Ebû Hâmid Muhammed b. Muhammed Gazzâlî, el-Maksadu'l-Esnâ fí Şerhi Esmâillâhi'l-Hüsnâ, 1. bs., Cidde, Dâru'l-Minhâc, 1439/2018, s. 59-60.

77 Gazzâlî, el-Maksadu'l-Esnâ, s. 71.

78 Gazzâlî, el-Maksadu'l-Esnâ, s. 83-84, 148.

79 Ebu'l-Mu'în Meymûn Nesefi, Bahru'l-Kelâm, tah. Veliyyüddîn Muhammed Salih e-Furfûr, 2. bs., y.y., 1421/2000, s. 100, 138-39.

80 Ebu'l-Mu'în Meymûn Nesefî, et-Temhîd li Kavâidi't-Tevhîd, tah. Habîbullah Hasan Ahmed, 1. bs., Kahire, 1406/1986, s. 377, 379.

81 Ebu'l-Mu'în Nesefî,, Tabsiratü'l-Edille, c. III, s. 1094-95. 


\subsection{9. Şehristânî (ö. 548/1153)}

Eş‘ariyye kelâmcılarından Şehristânî’nin eserlerini incelediğimizde, onun bazı kelimeler arasında fark gözetmesinden dolayı terâdüfü kabul etmediğini anliyoruz. "Vucûd-Vucûb"; "Vucûd-Sübût"; "Kesb, Îcâd, Halk: Halk"; "Mekân-Mahal"; "Emr-Halk"82 gibi. Şehristânî'nin bu kelimeler arasında terâdüf olmadığını söylemesi ve elimizdeki eserlerinde herhangi bir iki veya daha fazla kavramın müterâdif olduklarını söylememesi, onun Ehl-i Sünnet kelâmcılarının çoğunun aksine, bizde terâdüfü kabul etmediği kanaati uyandırmaktadır.

\subsubsection{Nûreddîn es-Sâbûnî (ö. 580/1184)}

Mâtürîdî kelâmcısı Nûreddîn es-Sâbûnî, eserlerinde genel olarak terâdüfü benimsemiş görünmektedir. "Vâhid-Ahad"; "Şey, Sübût, Vucûd"; "İsim-Müsemmâ"; "İmân-İslâm"; "İstitâ' 'at, Kudret, Kuvvet, Tâkat, Vüs ": Istitâ 'at"; "İrâde-Meşîet"; "Irâde-Rızâ" ${ }^{83}$ gibi.

\subsubsection{Fahreddîn er-Râzî (ö. 606/1210)}

Fahreddîn er-Râzî, usûl-i fikha dair eserinde müterâdifi tanımlayan kelâmc1lardandır. Ona göre müterâdif, "bir itibarla bir şeye delalet eden müfred lafızlardır." Râzî, burada "müfred” kaydıyla, resm ve hadden kaçındığını, zira bunların müterâdif olmaklarını söylemiştir. "Bir itibarla" kaydıyla da, iki sıfat açısından bir şeye delalet eden, -es-sârim ve el-mühenned (kılıç) gibi- veya sıfatın sıfatı olması itibarıyla bir şeye delalaet eden -el-fasîh ve en-nâtık (konuşan) gibi- iki lafızdan kaçındığını ifade etmiştir. Çünkü bu ikisi, birbirinden farklıdır. ${ }^{84}$

Râzî, bazı insanların müterâdifi inkâr ettiklerini, müterâdif zannedilen kelimeler arasında farklılık bulunduğunu iddia ettiklerini söylemiştir. Yine Râzî, iştikâkçilerin müterâdifi reddetmek için ileri sürdükleri delilleri zorlama olarak nitelendirmekte, bunların doğruluğuna dair aklî ve naklî deliller bulunmadığını, bu sebeple onların görüşlerinin terk edilmesi gerektiğini ifade etmektedir. ${ }^{85}$ Râzî, bir kısım insanların esasen iki nedenden dolayı terâdüfün olmadığını söylediklerini ifade etmekte ve o iki nedeni şöyle zikretmektedir:

82 Abdülkerîm Şehristânî, Nihâyetü'l-İkdâm fî 'İlmi'l-Kelâm, tah. Alfred Guillaume, London, Oxforf University Press, 1934, s. 54, 77, 151, 152, 244, 314-15.

83 Nûreddin Sâbûnî, el-Kifâye fi'l-Hidâye, tah. Muhammed Aruçi, Beyrut, Dâru İbn Hazm, 1435/2014, s. 68-70, 73, 102-106, 173, 175, 242, 367-68; Kitâbu'l-Bidâye, s. 82, 107.

84 Fahreddîn Muhammed b. Ömer Râzî, el-Mahsûl fî Usûli'l-Fikh, tah. Tâhâ Câbir Feyyâz el- 'Alvânî, 2. bs., c. I, Beyrut, 1412/1992, s. 253; Suyûtî, el-Müzhir, c. I, s. 402.

Râzî, el-Mahsûl, c. I, s. 254-55; Suyûtî, el-Müzhir, c. I, s. 403. 
1) Terâdüf, tam anlamaya engel olur. Çünkü iki muhataptan birinin bildiği isim diğerinin bildiğinden farklı olacaktır. Dolayısıyla konuşma esnasında birbirlerinin muradını anlayamayacaklardır. Böylece her biri diğerinin kelimesini ezberleme yoluna gidecektir ki, bu meşkakatli bir iştir.

2) Terâdüf, bilinenin tarifini içerir. Bu ise aslın hilâfınadır.

Râzî’nin üzerinde durduğu diğer bir mesele, iki müterâdiften her birinin diğerinin yerini tutmasının gerekli olup olmadığıdır. İlk bakışta açık olan, iki müterâdiften her birinin diğerinin ifade ettiği şeyi ifade etmesidir. Ancak ona göre böyle olması şart değildir. ${ }^{86}$ Râzî şöyle diyor: "Müsemmâ bir olmakla birlikte isimler çok olur. Müterâdif isimler gibi. Bazen de isim bir, müsemmâ çok olur. Müşterek isimler gibi. Bu da birbirinden başka olmayı gerektirir." ${ }^{" 87}$

Râzî, "Kelime, Kelâm, Kavl, Lafz, İbâre, Hadîs" lafızlarının tamamını şerh ettiğini, bunların yedincisi olan "nutk"un da iştikâk keyfiyyetinin, zikredilen lafizlarla mürâdif mi yoksa onlarla mübâyin mi olduğunun araştırılması, eğer mübâyenet varsa farkın belirtilmesi gerektiğini ifade etmektedir. ${ }^{88}$ Yine Râzî, otuz kelimenin "ilm"in mürâdifi olduğu zannedildiğini söyledikten sonra, bu otuz kelimeyi tek tek ele alarak bunların "ilim"den farklarını göstermiştir. ${ }^{89}$ Râzî, $\mathrm{Mu}$ "tezile ile girdiği polemikte "İdrâk" ile "Rü'yet" Râzî'ye göre "Vâhid" ile "Ahad" arasında çeşitli yönlerden fark vardır."

Buna karşın Fahreddîn er-Râzî, "Nefs-Zât" "92; "Şey-Mevcûd"'93 gibi kelimeleri müterâdif kabul etmiştir.

\section{Müterâdif Kabul Edilen Kelimeler Arasındaki Farklar}

Kelâmcıların kâhir ekseriyeti terâdüf kavramının açıklamasını yapmaksızın pekçok kelâmî ve itikâdî kavramı müterâdif kabul etmişlerdir. Bir kısım kelâmcı da, bazı itikâdî ve kelâmî kavramları müterâdif kabul ederken bazıları arasında fark gözetmişlerdir. Çok az sayıda kelâmcı da bu kavramlar arasında mutlaka

86 Râzî, el-Mahsûl, c. I, s. 256-57.

87 Fahreddîn Muhammed b. Ömer Râzî, et-Tefsîru'l-Kebîr (Mefâtîhu'l-Gayb), 1. bs., c. I, Beyrut, Dâru'l-Fikr, 1401/1981, s. 116.

88 Râzî, et-Tefsîru'l-Kebîr, c. I, s. 28.

89 Râzî, et-Tefsîru'l-Kebîr, c. II, s. 222-26.

90 Fahreddîn Muhammed b. Ömer Râzî, Kitâbu'l-Erba î̀n fî Usûli'd-Dîn, 1. bs., Haydarabad, 1353h., s. 213-14.

91 Râzî, Levâmi 'u'l-Beyyinât, s. 230-31.

92 Râzî, el-Erba în, s. 361.

93 Fahreddîn Muhammed b. Ömer Râzî, Levâmi 'u'l-Beyyinât Şerhu Esmâillâhi Te 'âlâ ve 's-Slfât, Misir, 1323h., s. 260. 
fark olduğunu belirtmiştir. Burada müterâdif oldukları söylenen temel kelâmî kavramlardan bazılarını ele alarak, bunlar arsında fark olduğunu iddia eden âlimlerin görüşlerini açıklamaya çalışacağız.

\subsection{Vasf-Sifat}

Bazı kelâmcılar bu iki kelime arasında fark olmadığını ${ }^{94}$ belirtirken, bazıları bunlar arasında fark olduğunu ${ }^{95}$ söylemiştir.

Cürcânî, kelâmcıların vasf ile sıfat arasında fark gözettiklerini, vasf'in vâsıf (vasıflayan), sıfat'ın ise mevsûf (vasıflanan) yerine konulduğunu söylemiştir. O, "Vasf, fâil ile kâim olandır" denildiğini de ilave etmiştir. ${ }^{96}$

İbn Teymiyye, sifat ile vasf arasında fark gözetildiğini, sıfatın "söz", vasfın "mevsuf ile kâim manâ" sayıldığını nakletmiştir."

Vasf ile slfat arasındaki fark hususundaki diğer bir açıklama şöyledir: "Vasf masdardır. Slfat ise, fi 'letün kalıbındadır. Bu kalıp nâkıstır. Sıfat kelimesinin aslının, visfetun şeklinde olduğu ve bu kelimenin vasf'tan daha özel olduğu söylenmiştir. Çünkü vasf, bir şeyin çoğu için de azı içinde geçerli olan cins ismidir. Sifat ise, bir -vasf çeşididir; oturan ve yürüyenenin şekli olan cilsetun (oturuş) ve mişyetün (yürüyüş) gibi. Bu yüzden sıfatlar, manâlar hakkında kullanılır. Örneğin, "Afâf (iffet) ve hayâa' (utanma) mü' minin sıfatlarındandır" denilir; ancak "Bunlar onun vasıflarındandır" denilmez. Çünkü vasf, ancak bir söz olabilir. Hâlbuki slfat, her ne kadar ortada bir "hey'et" (şekil) olmasa da, "hey'et" yerine kullanılır. Illim ve kudret gibi manâlar için sıfât (sıfatlar) denilir. Çünkü bunlarla mevsuf birisi düşünülür."’98

İsmail Hakkı Bursevî ise, vasf ile sıfat arasındaki farkı şöyle açıklamıştır: "Vasf, vasıflayanda bulunan bir şeydir ve bunun intikali câizdir; utanma kırmız1lığı, korku sarılığ gibi. Sifat ise, vasıflananda bulunan ve değişmeyen bir şeydir; uzunluk, kısalık, Zenci için siyahlık, Rûmî için beyazlık gibi." ${ }^{99}$

Görüldüğü üzere bazı âlimler, lügavî açıdan her iki kavram arasında fark gözetmişlerdir.

94 İbn Fûrek, a.g.e., s. 38; Bâk1llânî, Kitâbu Temhîdi'l-Evâil, s. 244-48.

95 Âmidî, Gâyetü'l-Merâm, s. 133.

96 Cürcânî, et-Ta'rîfât, s. 211.

97 Takiyyüddîn Ahmed b. Abdulhalîm İbn Teymiyye, Mecmû'u'l-Fetevâ, c. III, Medine, 1425/2004, s. 335.

98 Askerî, el-Furûk, s. 31.

99 İsmail Hakkı Bursevî, Kelimeler Arasındaki Farklar (Kitâbu'l-Furuk), çev. Ömer Aydın, 2. bs., İstanbul, İşaret Yayınları, 2016, s. 354. 


\subsection{Halk-İbdâ6}

Kelâmcıların bir kısmı bu iki kelimenin müteradif olduklarını söylerken ${ }^{100}$, bir kısmı da aralarında fark olduğunu ${ }^{101}$ belirtmişlerdir. Burada önce halk kelimesinin sözlük anlamını ortaya koyarak diğer kelimelerle arasındaki farklara işaret edeceğiz.

İbdâ' 'ile halk: arasındaki farklar şöyle ifade edilmiştir:

1) İbdâ', bir şeyi yoktan îcâddır. İbdâ', "eysi leysten, varlığ yokluktan yaratmaktır" denilmiştir. Halk, bir şeyi bir şeyden îcâddır. İbdâ', halktan daha geneldir. Buna şu âyetler delâlet etmektedir: "O, göklerin ve yerin ibdâ ' edicisidir." (Bakara, 2/117); "Allâh'ın gökleri ve yeri halk ettiğini görmedin mi?" (İbrâhîm, 14/19)

$\mathrm{Bu}$ âyetlerde göklerin ve yerin yaratılması hakkında $i b d \hat{a}$ ' ve halk kelimeleri kullanıldığ 1 halde, Kur'ân-1 Kerim'de insanın yaratlıması hakkında ibdâ ' kelimesi ve türevleri kullanılmamıştır. ${ }^{102}$

2) İbdâ', bir şeyi bir defada îcâddır. ${ }^{103}$

İbdâ' dışında "yaratma" anlamına gelen bazı kelimeler de halk manâsında kullanılmıştır. Kısaca halk ile bu kelimeler arasındaki farklar şöyle ifade edilmiştir:

Halk'ta, yaratmanın özel bir keyfiyyet üzere olması dikkate alınmıştır.

Îcâd' da, sadece varlığın ibdâ‘ yönü dikkate alınmıştır.

İhdâs'ta, hudûs ve hâdis olma açısından yaratma yönü dikkate alınmıştır.

$\dot{I} b d \hat{a}$ 'da, önceden geçmemiş bir keyfiyette yaratma yönü dikkate alınmıştır.

İhtirâ 'da, kolayca türetme yönü dikkate alınmıştır.

Takdîr'de sadece sınırlama ve belirleme yönü dikkate alınmıştır.

Tekvîn'de, oluş ve bekâ yönünden yaratma yönü dikkate alınmıştır.

Ca 'l'de, ilişki ve irtibâtı meydana getirme yönü dikkate alınmıştır. ${ }^{104}$

100 İbn Fûrek, Makâlât, s. 26.

101 Gazzâlî, el-Maksadu'l-Esnâ, s. 148.

102 Cürcânî, et-Ta 'rîfât, s. 8, 10; Ebu'l-Bekâ, el-Külliyyât, s. 29.

103 Ebu'l-Bekâ, el-Külliyyât, s. 29.

104 Mustafavî, et-Tahkîk, c. III, s. 127-28. 


\subsection{Rahmân-Rahîm}

Bazı âlimler, Rahmân ve Rahîm isimleri aynı manâda (müterâdif) kabul ederken, bazıları bu iki isim arasında fark olduğunu ifade etmişlerdir. Rahmân ve Rahîm isimleri arasında manâ bakımından bir fark gözetmeyen âlimler, bu iki ismi, lafızları farklı olsa da aynı manâda kabul ederler; nedîm-nedmân kelimeleri gibi. ${ }^{105} \mathrm{Bu}$ iki isim arasında fark gözetenler ise, bu farklar hususunda değişik izahlar yapmışlardır:

İbn Abbâs'tan rivayet edildiğine göre, Rahmân, Rahîm'den daha rakîktir (incedir). O, bununla Rahmân'ın manâ bakımından daha belîğ olduğunu kasdetmiştir. Çünkü Allah Teâlâ, rikkat (incelik) ve gilza (kabalık) ile vasıflanmaz. ${ }^{106}$

Ebû Ubeyde’ye göre Rahmân'ın mecâzı “zü’r-rahme” (rahmet sahibi), Rahîm'in mecâzı ise "râhim" (rahmet eden)dir. ${ }^{107}$

Başka bir görüşe göre Rahîm, "rahmet şânından olan" demektir. Rahmân ise, Allah'a mahsus bir isimdir. ${ }^{108}$

Rahmân'ın husûsî isim, umûmî sıfat; Rahîm'in umûmî isim, husûsî sıfat olduğu söylenmiştir. Rahmân'1n daha fazla övgü içerdiği, Rahîm'in daha latif olduğu söylenmiştir. ${ }^{109}$

Ebû Hilâl el-Askerî’ye göre Rahîm, udûlden (râhim kalıbından döndüğünden) dolayı mübâlağadır. Rahmân ise, daha da mübâlağalıdır; çünkü ondaki udûl daha fazladır. Mübâlağa udûle göre olunca, udûl daha fazla olanda mübâlağa da daha fazla olur. ${ }^{110}$

İmâm Mâtürîdî'ye göre Rahmân ve Rahîm isimlerinden biri diğerinden daha rakîk (ince)dir. O, Rahmân isminin sadece Allah Teâlâ'ya mahsus olduğunu ve onunla başkasının isimlendirilemeyeceğini; Rahîm isminin ise başkasına verilebileceğini; bu yüzden Rahmân'ın zâtî, Rahîm'in ise fiilî sıfat olduğunu söylemektedir. ${ }^{111}$

105 Cevherî, es-Sihâh, s. 433; Ebû Hâtim er-Râzî, ez-Zîne, C., s. 176; İbn Fûrek, Makâlât, s. 48; Cüveynî, Kitâbu'l-İş̧âd, s. 128.

106 Ebû Hilâl el-Askerî, el-Furûk, s. 195.

107 Ebû Hâtim er-Râzî, ez-Zîne, c., s. 176.

108 Ebû Hilâl el-Askerî, el-Furûk, s. 195.

109 Ebu'l-Bekâ, el-Külliyyât, s. 467.

110 Ebû Hilâl el-Askerî, el-Furûk, s. 195.

111 Mâtürîdî, Te 'vîlâtu'l-Kur'ân, c. I, s. 15-16; Ebû Hâtim er-Râzî, ez-Zîne, c., s. 176, 177; Râgıb el-İsfahânî, el-Müfredât, s. 254. 
Allah Teâlâ için“dünyanın Rahmân'1, âhiretin Rahîm'i” denilmiştir. Buna göre O'nun ihsânı dünyada mü'minleri ve kâfirleri kapsar; âhirette ise sadece mü’ninlere özgüdür. ${ }^{12}$

Gazzâlî, Rahmân ve Rahîm isimleri arasındaki farkı şöyle açıklar: "Rahmân, Rahîm'den daha husûsîdir. Bunun için Allah'tan başkasına "Rahmân" ismi verilmez. "Rahîm", O’ndan başkası hakkında kullanılabilir. Bu açıdan Rahmân, kesin olarak rahmetten türemişse de, Allah'ın özel ilmi yerine geçen ismine yakındır. Bundan dolayı Allah bu iki ismi bir araya getirerek şöyle buyurmuştur: "De ki: İster Allah diye duâ edin, ister Rahmân diye duâ edin!" (İsrâ, 17/110) Rahmetten bir nevi olan Rahmân'ın anlamının, kulların makdûrâtından uzak olması çok zordur. O, uhrevî saâdetle ilgilidir. İlk olarak Rahmân, kullarına icâd yoluyla şefkatli olmaktır. İkinci olarak, imâna ve sâadet yollarına hidayettir. Üçüncü olarak, uhrevî saâdet hususunda rahmettir. Dördüncü olarak, kerîm yüzüne bakma nimetini bahşetmektir. ${ }^{113}$

Yapılan açıklamalardan anlaşıldığ 1 üzere, "rahmet" kökünden türeyen Rahmân ve Rahîm isimleri arasında bir takım belirgin farklar vardır.

\subsection{Rü’yet-İdrâk}

Bazı kelâmcılar, "rü'yet" ile "idrâk"in aynı manâda olduğunu söylemiştir."14 Bazı kelâmcılar da her iki kelime arasında fark olduğunu söylemişlerdir.

Fahreddîn er-Râzî’ye göre idrâk, "rü’yet”ten ibaret değil, "vusûl"den (ulaşmadan) ibarettir. Bir kimsenin bir şeyi, onun etrafını ve sonunu görmesi ve onun her yönünü ihata etmesi anlamında "onu idrâk etti" denilir. İdrâk, her yönden kuşatıcı bir rü'yettir (görmedir.) $)^{115}$

Devvânî’ye göre idrâk, "rü'yet" demektir. Ancak idrâkin hakikati, nâil ve vâsıl olmaktır. İhâtaya mukârin rü'yet, mutlak rü’yetten daha özledir. ${ }^{116}$

İbn Hazm'a göre, lügatte idrâk, "nazar" ve "rü’yet” üzerine zâid bir manâdır. Çünkü idrâkte, rü’yette bulunmayan "ihâta" manâsı vardır."117

Rü'yet ile idrâk arasındaki en temel fark, rü'yete nazaran idrâkin her yönden kuşatıcı olmasıdır.

112 Râgıb el-İsfahânî, el-Müfredât, s. 254.

113 Gazzâlî, el-Maksadu'l-Esnâ, s. 123.

114 İbn Fûrek, Makâlât, s. 81.

115 Râzî, Kitâbu'l-Erba 'în, s. 213-14.

116 Devvânî, Şerhu'l-Akâidi'l-Adudiyye, s. 98-99.

117 İbn Hazm, el-Fasl, c. III, s. 8. 


\section{5. İrâde-Meşîet}

Kelâmcıların çoğuna göre "meşîet" ile "irâde" aynı anlamdadır. ${ }^{118}$ Ancak Ebû Hanife başta olmak üzere bazı kelâmcılar ${ }^{119}$, her iki kelime arasında fark olduğunu söylemişlerdir. Râgıb el-Isfahânî şöyle demektedir: "Bazı kelamcılara göre aslında meşîet, "bir şeyin icâdı ve ona isâbet"tir. Her ne kadar örfte irâde yerine kullanılırsa da, meşîet Allah Teâlâ'dan olursa "îcâd", kuldan olursa "isâbet"tir. Allah'tan olan meşîet, şeyin varlı̆̆ını gerektirir. Bunun için, “Allah'ın dilediği olur, dilemediği olmaz" denilmiştir. Allah'ın irâdesi ise mutlaka murâdın vücuda gelmesini gerektirmez. Nitekim Allah şöyle buyurmuştur: "Allah, sizin için kolaylık ister, zorluk istemez." (Bakara, 2/185); "Allah, kullarl için hiçbir zulüm murâd etmez." (Mü’min, 40/31) Bilinmektedir ki, zorluk ve zulüm insanlar arasında meydana gelir. Bu ikisi arasındaki fark konusunda şöyle denilmiştir: Bazen insanın irâdesi, Allah'ın irâdesi onun irâdesinden önce bulunmamak üzere meydana gelebilir. Zira insan ölmemeyi murâd eder, ama Allah bunu kabul etmez. İnsanın meşîeti ise mutlaka Allah'ın meşîetinden sonra olur. Nitekim Allah, “Allah, dilemedikçe siz dileyemezsiniz." (İnsan, 76/30) buyurmuştur." 120

Ebû Hilâl, irâde ile meşîet arasındaki fark1 şöyle açıklamıştır: "İ̉âde, vakti geçmiş bir şey için de geçmemiş bir şey için de olur. Meşîet ise, vakti geçmiş bir şey için olur. Meşîet'in mukâbili ibâ' (reddetme) kelimesidir. Bir şeyi reddetmek, ancak yapma girişimi esnasında olur. Aynı şekilde meşîet de, ancak yapma girişimi esnasinda olur." 121

İsmail Hakk1 Bursevî ise irâde ile meşîet arasındaki fark konusunda şöyle demiştir: "Meşîet, sadece oluşlarda olur. İrâde, bazen oluşlarda ve bezen hükümlerde olur." 122

\section{6. İhtiyâr-İrâde}

Kelâmcılardan bazıları ihtiyâr ile irâdeyi aynı anlamda görürken ${ }^{123}$, bazıları bunlar arasında fark gözetmiştir. Ebû Hilâl, irâde ile ihtiyâr arasındaki fark1 şöyle açıklamıştır: "Ihtiyâr, bir şeyi başka bir şeye bedel olmak üzere irâde etmektir.

118 Bkz. İbn Fûrek, Makâlât, s. 52; Bâkıllânî, el-İnsâf, s. 43; Beyhakî, el-Esmâ, c. I, s. 349; elI' 'tikâd, s. 8; Râgıb el-İsfahânî, el-Müfredât, s. 371; Tûsî, Telhîsü’l-Muhassal, s. 169; Sâbûnî, el-Kifâye, s. 175; Kitâbu'l-Bidâye, s. 82; Teftazânî, Şerhu'l-Akâid, s. 41, 56; Şerhu'l-Makâsıd, c. IV, s. 134; Beyâzîzâde, İşârât, s. 264; Ebu'l-Bekâ, el-Külliyyyât, s. 75.

119 Bkz. İbnü'l-Hümâm, Kitâbu'l-Müsâmera, c. II, s. 8.

120 Râgıb el-İsfahânî, el-Müfredât, s. 471-72.

121 Ebû Hilâl el-Askerî, el-Furûk, s. 124.

122 Bursevî, Kelimeler Arasindaki Farklar, s. 373.

123 Bkz. Tûsî, Telhîsü'l-Muhassal, s. 169. 
İhtiyâr, tercih edilen şey ile başkasının aynı anda kalbe doğmasıyla olmaz. Ĕger kalbe başka bir şey doğmuyorsa, bu bir fiil için irâde olur. İhtiyârın aslı, "hayr"dır. Muhtâr (ihtiyâr sahibi), zorlama ve mecburiyet olmaksızın gerçekte iki şeyden en hayırlısını veya kendisine göre iki şeyden hayırlısını irâde eden kimsedir. İnsan, bir şeyi irâde etmeye zorlanırsa, ona muhtâr denilmez. Çünkü ihtiyâr, ıztırârın (zorunluluğun) zıddıdır."124

\section{7. İstitâ'at-Kudret}

Bazı kelâmcılar istitâ 'at ve kudret kavramlarını müterâdif (eş anlamlı) kabul ederken ${ }^{125}$, bazıları da bunlar arasında fark gözetmiştir. Ebû Hilâl, istitâ 'at ile kudret arasındaki farkı şöyle açıklamıştır: "İstitâ'at, "boyun eğme" anlamına gelir. Bu nedenle Allah, istitâ 'at ile nitelenmez... İstitâ 'at, "icâbet" anlamına da gelir. Allah Teâlâ'nın, "Rabbinin istitâ ' $ı$ var mı?" (Mâide, 5/112) sözü, "Senin isteğine icâbet eder mi?" demektir. Ancak Allah'ın, İşitmeye istitâ'at getiremezlerdi" (Kehf, 18/101) âyeti ise, onların buna kudretlerinin olmadığı anlamında değil, "Kur'ân’1 dinlemek kendilerine ağır gelirdi” anlamındadır."126

\subsection{Nebî-Resûl}

Bazı kelâmcılar nebî ile resûl arasındaki farklardan bahsetmişlerdir. Örneğin, "Her resûl nebîdir; fakat her nebî resûl değildir"127 denilmektedir. Yine "Resûl, teblîğle emrolunan, nebî ise teblîğden haber veren zâttır." denilmiştir. Bazıları ise şöyle demiştir: "Resûl, kendisine vahiy ve kitap indirilen peygamber, nebî ise kendisine özel vahiy gelmeyen, başka resûlün şeriatini haber veren zâttır." ${ }^{28}$

Ebû Hilâl, resûl ile nebî arasındaki farkı şöyle açıklamıştır: "Nebî, ancak mu'cize sahibi olur. Resûl, Allah'tan başkasının elçisi de olabilir. Dolayısıyla resûl, mu'cize sahibi değildir. Bir şeyden inbâ' (haber verme), bir haber (nebe') taşımaksızın da olur. Fakat irsâl (elçi gönderme), ancak bir haber taşımakla olur. Nübüvvet kelimesi, genellikle nebî kelimesiyle tamlama oluşturur ve nübüvvetü'n-nebî (nebînin nübüvveti) denilir. Çünkü nebî, nübüvvetin fâili olması sebebiyle nebî sıfatını almaya hak kazanmıştır. Risâlet ise, -resûl Allah tarafından gönderildiği için- Allah'a nisbet edilir... Risâlet, resûlün bir başkasına iletmek üzere üstlendiği beyânın tamâmıdır. Nübüvvet ise, risâleti yerine getirme yü-

124 Ebû Hilâl el-Askerî, el-Furûk, s. 124.

125 Bkz. İbn Fûrek, a.g.e., s. 45, 109; İbn Hazm, el-Fasl, c. III, s. 36; Sâbûnî, el-Kifâye, s. 242; Kitâbu'l-Bidâye, s. 107; Cürcânî, Ta 'rîfât, s. 35, 221.

126 Ebû Hilâl el-Askerî, el-Furûk, s. 110.

127 İbn Fûrsek, Makâlât, s. 180.

128 Mâtürîdî, Te'vîlâtu'l-Kur'ân, c. IX, s. 195-96. 
kümlülüğüdür. $\mathrm{Bu}$ nedenle, risâletlerin tebliğ edilmesi câiz, nübüvvetlerin tebliğ edilmesi ise câiz değildir." 29

Kur'ân'da bir de resûl ile aynı kökten türeyen mürsel kelimesi vardır. Bunlar, bazen aynı manâda kabul edilmişlerdir. ${ }^{130}$ Ebû Hilâl, mürsel ile resûl arasındaki fark1 şöyle açıklamıştır: "Mürsel, bir başkası tarafindan elçi olarak kullanılmayı gerektirir. Rasûl ise, elçilik vasıtasıyla elçinin dilinin kullanılmasını gerektirir." 131

\subsection{Nefs-Rûh}

Râgıb el-Isfahânî, rûh ile nefs arasındaki ilişki hakkında şöyle demektedir: "Rûh, nefs için bir isimdir. Çünkü nefs rûhun bir kısmıdır. Bu, tıpkı nev'in cinsin ismiyle isimlendirilmesi ve insanın hayvan diye isimlendirilmesi gibidir. Böylece rûh, sayesinde hayat, hareket elde ettiği, bir takım menfaatler kazandığı ve bazı zararları defettiği parçasının ismiyle isimlendirilmiştir." 132

İbn Hazm'a göre nefs ve rûh bir müsemmâya ait müterâdif iki isimdir ve ikisinin de manâsı aynıdır. ${ }^{133}$

Ebû Hilâl, rûh ile nefs arasındaki fark1 şöyle açıklamıştır: "Rûh, rîh (rüzgâr) cinsinden rakîk (şeffaf) bir cisimdir. Arapça rûh ve rîh (rüzgâr) aynı köktendir. Bundan dolayı nefh (üfleme) kelimesi kullanılır... Cebrâîl (as) rûh diye isimlendirilmiştir. Çünkü insanlar, rûhtan faydalandıkları gibi, dinleri hususunda ondan faydalanmaktadırlar. Bu anlamdan dolay "Kur'ân" da rûh diye isimlendirilmiştir. Nefs, hem rûh ve hem zât için kullanılan müşterek bir lafızdır. Te'kîd olarak kullanılır... Nefs, aynı zamanda "su" anlamında olup çoğulu enfâs'tır... Nefs, avucun deriyle dolu olmasıdır. Zât manâsına uygun olan nefs, bir şeye bir yönden özgü olandır." 134 Ayrıca rûha "nefs" denilmesinin, sonradan ortaya çıkmış felsefî̀ bir 1sıtılah ${ }^{135}$ olduğu da söylenmektedir.

\subsection{0. İmân-İslâm}

İmân ve islâmın eş anlamlı olup olmadığı konusunda üç farklı görüş ortaya çıkmıştır:

129 Ebû Hilâl el-Askerî, el-Furûk, s. 268-69.

130 Zebîdî, Tâcü'l-Arûs, c. XXIX, s. 73.

131 Ebû Hilâl el-Askerî, el-Furûk, s. 269.

132 Râgıb el-İsfahânî, el-Müfredât, s. 369.

133 İbn Hazm, el-Fasl, c. V, s. 202, 221.

134 Ebû Hilâl el-Askerî, el-Furûk, s. 103.

135 Mustafavî, et-Tahkîk, c. XII, s. 219. 
1) İmân ve islâmın bir olduğunu söyleyenler. ${ }^{136}$

2) İmân ve islâmın farklı anlamda olduğunu söyleyenler. ${ }^{137}$

3) İmân ve islâmın ayrı ayrı şeyler olduklarını, ancak birbirleriyle irtibatları bulunduğunu söyleyenler. ${ }^{138}$

Ebû Hilâl, imân ile islâm arasındaki fark konusunda şöyle demektedir: "İmân, Allah'a öyle bir itâattir ki, bu itâat, zıddı olan ikâbdan (cezadan) emîn kılar. Bu itâate bağlı olmaları bakımından nâfile ibâdetler imân olarak isimlendirilmiştir. Islâm ise, Allah'a öyle bir itâattir ki, bu itâat sâyesinde kişi Allah'ın ikâbından (cezasından) sâlim olur. İslâm, Hz. Muhammed'in (s.a.v.) getirdiği şerî‘atin özel ismi gibi olmuştur. Bu nedenle Yahûdiler ve diğerleri imân kapsamı dışında tutulmadıkları hâlde, islâm kapsamı dışında tutulmuşlardır." 139

\subsection{1. İlim-Ma'rifet}

Kelâmcılar, genel olarak ilim ve ma 'rifet kelimelerini müterâdif kabul etmişlerdir. ${ }^{140}$

Ebû Hilâl, ilim ile ma 'rifet arasındaki farkı şöyle izah etmiştir: Ma 'rifet, ilim kelimesinden daha özeldir. Çünkü ma 'rifet, bir şeyi diğerlerinden ayrırak özünü bilmektir. İlim, mücmel de mufassal da olur. Zührî, “Ben Allah’1 Ârif olarak vasıflamam; ancak bu şekilde niteleyenleri de kınamam. Çünkü ma'rifet, "evin sayesinde tanındığı izler" anlamındaki 'irfânu'd-dâr ifadesinden alınmıştır” demiştir. Zührî'ye göre Allah'ın, eşyâyı eser ve delîl vasıtasıyla bilmesi câiz değildir. O, "Ma 'rifet, bilinenleri temyiz etmektir" diyerek, Allah'ın Ârif olarak vasıflanmasının doğru olmadığı gibi, "mümeyyiz" olarak vasıflanmasının da doğru olmadığını ima etmiştir. Her ma 'rifet "ilim"dir; ancak her ilim "ma"rifet" değildir. Bu durumda ma 'rifet kelimesi, "bilineni, başkalarından temyîz etme"yi ifâde eder. Ancak ilm, bilineni zikretme husûsunda başka bir tür tahsis bulunmadıkça bu anlamı ifade etmez. ${ }^{141}$

136 Mâtürîdî, Kitâbu 't-Tevhîd, s. 394-95; Te'vîlâtu'l-Kur'ân, c. II, s. 313; Nesefi, Bahru'l-Kelâm, s. 151; Bâkıllânî, Kitâbu Temhîdi'l-Evâil, s. 390-92; el-İnsâf, s. 56; Beyhakî, el-İ tikâd, s. 271; Ebu'l-Mu'în Nesefî, Tabsiratü'l-Edille, c. III, s. 1094-95; Cüveynî, el- 'Akîdetü'n-Nizâmiyye, s. 87; Pezdevî, Usûlu'd-Dîn, s. 157, 228; Sâbûnî, el-Kifâye, s. 367-68.

137 Eş'arî, el-İbâne, s. 10; Bâkıllânî, Kitâbu Temhîdi'l-Evâil, s. 390-92; el-İnsâf, s. 56.

138 İbn Hazm, el-Fasl, c. III, s. 269-70; İbn Ebi'l-İzz, Şerhu'l-Akîdeti 't-Tahâviyye, c. II, s. 490.

139 Ebû Hilâl el-Askerî, el-Furûk, s. 228.

140 İbn Hazm, el-Fasl, c. V, s. 242; İbn Fûrek, a.g.e., s. 6, 45; Bâk1llânî, el-İnsâf, s. 13.

141 Ebû Hilâl el-Askerî, el-Furûk, s. 80-81. 
Bursevî, ilim ile ma 'rifet arasındaki fark konusunda şunları söyler: "Ma 'rifet, hakikatlerdeki özellikleri ve üstünlükleri idrâk etmektir. İlim ise, hakikatleri ve gereklerini idrâk etmektir." ${ }^{142} \mathrm{O}$, eserinin başka yerinde ilim ile ma 'rifet arasında şu farkların bulun duğunu ifade etmiştir:

1) Ma 'rifet cüz'̂̂lerde, ilim ise küllîlerde kullanılır.

2) İlim mürekkeblerde, ma 'rifet basîtlerde kullanılır. Bu yüzden, 'areftu'llâhe "Allâh'ı bildim" denilir; 'alimtuhu denilmez.

3) Ma'rifet cehaletten sonra idrâki ve son iki idrâk arasına bir şeyin girdiğini ve bu ikisi arasında bir yokluk bulunduğunu bilmek hakkında kullanılır. Bu iki kayıttan hiçbiri ilim hakkında geçerli değildir." ${ }^{143}$

Ebu'l-Mu'în en-Nesefî, ilim ile ma 'rifet bir olduğu için Allah Teâlâ'nın, âlim gibi ârif olarak vasıflanacağını söyleyen Kerrâmiyye'nin bu görüşüne iltifat edilemeyceğini ifade etmektedir. Çünkü müslümanların icmâ bunun hilafinadır. Zira ma'rifet, mutlak ilmin değil sonradan ortaya çıkan bir amelin ismidir. ${ }^{144}$

Hem sözlük anlamlarından hem de âlimlerin açıklamalarından ilim ile ma'rifetin müterâdif olmadıkları anlaşılmaktadır.

\section{Sonuç}

Bir veya daha fazla kelimenin aynı anlama gelmesi demek olan terâdüf, aslında bir dil problemi olmakla birlikte, o dilde yapılan bütün ilimleri etkilemesi bilinen bir gerçektir. Her dil için yapılan bu tartışmayı, biz bu çalışmamızda kelâm ilmi açısından yapmaya gayret sarfederek bazı önemli sonuçlara ulaştık. Her şeyden önce İslâm dünyasında terâdüf konusunun ilgili çalışamalarda müstakil bir çalışma hâlinde veya en azından bir bölüm içinde Arap dili, tefsir, usûl-i fıkıh, mantık gibi ilimler açısından ele alındığını, ancak kelâm alanında konuyla ilgili yapılmış makale, tez veya kitap tarzında herhangi bir çalışma tespit edemediğimizi ifade etmek isteriz. Ayrıca hadis alanında da bir çalışma yapılmamış olması da dikkat çekici bir durumdur. Öte yandan kelâmcıların kahir ekseriyeti, terâdüfün varlığı ve yokluğu sorununu tartışmamışlar, terâdüf (veya müterâdif) ya da bu anlamı ifade eden bir kavramı doğrudan kullanarak görüşlerini ifade etmişlerdir. Terâdüf kavramını tartışan kelam âlimleri arasında özellikle Gazzâlî ile Fahreddin er-Râzî’yi görüyoruz.

142 Bursevî, Kelimeler Arasindaki Farklar, s. 402.

143 Bursevî, Kelimeler Arasindaki Farklar, s. 356.

144 Nesefî, Ebu'l-Mu'în, Tabsiratü'l-Edille, c. I, s. 131. 
Kelâm tarihinde, terâdüf kavramı terim olarak henüz ortaya çıkmamış olsa da, Ebû Hanîfe örneğinde olduğu gibi çok erken dönemden itibaren anlamca biribirine yakın bazı kelimeler arasındaki farkların âlimler tarafından belirtildiğini görüyoruz.

Ehl-i Sünnet kelâmcılarının görüşlerini temel alarak ortaya koyduğumuz bu çalışmada, çoğu kelâmcının terâdüfü kabul ettiğini, bazı kelâmcıların ise kimi kelimeleri müterâdif kabul ederken kimileri arasında fark gözettiğini görüyoruz. Çok sayıda kavram üzerinde durmasalar da, Ebu'l-Yusr el-Pezdevî ve Şehristânî'nin kelâmî kavramlar arasında terâdüf bulunduğunu kabul etmediklerini söyleyebiliriz. Bu konuda terâdüfe kesin olarak kapılarını kapatan âlimin İbn Teymiyye olduğunu ifade etmek gerekir.

Çalışmamızda müterâdif olduğu iddia edilen kavramlardan bazı örnekleri inceleyerek aralarında farklar olduğu lügatler, furûk kitapları, kelâm eserleri ve diğer kaynaklardan istifade edilerek açıklanmaya çalışılmıştır. 


\section{Kaynakça}

Abbûd, Mârûn, Edebü'l-Arab, Kahire, Müessesetü Hindâvî, 2014.

Abdutevvâb, Ramazan, Fusûl fî Fıkhi'l- 'Arabiyye, 6. bs., Kahire, 1420/1999.

Ali el-Kârî, Ali b. Sultân Muhammed, Minehu'r-Ravzi'l-Ezher fî Şerhi'l-Fıkhı'l-Ekber, 1. bs., Beyrut, 1419/1998.

Alvânî, Mustafa, "Arap Dilinde Terâdüf (Eşanlamlılık)”, Cumhuriyet Üniv. Ilahiyat Fak. Dergisi, çev. Galip Yavuz, sayı 1, 1996.

Âmidî, Seyfüddîn, Ebkâru'l-Efkâr fî Usûli'd-Dîn, tah. Ahmed Muhammed el-Mehdî, 2. bs., Kahire, 1424/2004. yad, $1424 / 2003$. , el-İhkâm fî Usûli'l-Ahkâm, tah. Abdurrezzâk Afîfî, 1. bs., Ri, Gâyetü'l-Merâm fî 'İmi’l-Kelâm, tah. Ahmed Ferîd el-Mezîdî, 1. bs., Beyrut, 1424/2004.

Aydın, Ömer, İslâm İnanç Esasları, 3. bs., İstanbul, 2015.

Bâkıllânî, Kâdî Ebû Bekr Muhammed b. Tayyib, el-İnsâffî mâ Yecibu I'tikâduhu ve lâ Yecûzü'l-Cehlü bihi, tah. Muhammed Zâhid el-Kevserî, 2. bs., Kahire, $1421 / 2000$.

, Kitâbu Temhîdi'l-Evâil ve Talhîsi'd-Delâil, tah. İmâduddîn Ahmed Haydar, 1. bs., Beyrut, 1407/1987.

Beyâzîzâde, Kemâlüddîn Ahmed b. Hasan, İşârâtu'l-Merâm min İbârâti'lImâm Ebî Hanîfe en-Nu 'mân, tah. Ahmed Ferîd el-Mezîdî, Beyrut, 1428/2007.

Beyhakî, Ebû Bekr Ahmed b. el-Hüseyin, el-İtikâd ve'l-Hidâye ilâ Sebîli'r-Reşâd, tah. Ebû Abdullah Ahmed b. İbrâhîm Ebu'l-'Ayneyn, Riyad, $1420 / 1999$.

, el-Kazâ ve'l-Kaderve'r-Red 'alâ men Yahteccü bi'l-Kader, tah. Ebu'l-Fidâ el-Eserî, Beyrut, 1409/1989.

, Kitâbu'l-Esmâ ve's-Sıfât, tah. Abdullah b. Muhammed el-Hâşidî, Cidde, Mektebetu's-Sevâdî li’t-Tevzî', 1412/1991.

Bû Mulhim, Ali, el-Menâhi'l-Felsefiyye 'inde'l-Câhız, 2. bs., Beyrut, 1988.

Bursevî, İsmail Hakkı, Kelimeler Arasındaki Farklar (Kitâbu'l-Furuk), çev. Ömer Aydın, 2. bs., İstanbul, İşaret Yayınları, 2016.

Câhız, Amr b. Bahr, Kitâbu'l-Hayevân, tah. Abdüsselâm Muhammed Hârûn, 2. bs., y.y., 1384/1965. 
Cebel, Muhammed Hasan Hasan, el-Mu'cemu'l-İştikâkî el-Muassal li Elfâzi'l-Kur'âni'l-Kerîm, 1. bs., Kahire, Mektebetü'l-Âdâb, 2010.

Cevherî, Ebû Nasr İsmâîl b. Hammâd, Tâcu'l-Lüga ve Sihâhu'l-Arabiyye, Kâhire, Dâru'l-Hadîs, 1430/2009.

Cürcânî, Ali b. Muhammed es-Seyyid eş-Şerîf, Mu'cemu't-Ta 'rîfât, tah. Muhammed Sıddîk el-Minşâvî, Kahire, Dâru'l-Fazîle, t.y.

, Şerhu'l-Mevâklf, çev. Ömer Türker, İstanbul, T.C. Türkiye Yazma Eserler Kurumu Başkanlığ 2015.

Cüveynî, İmâmu'l-Haremeyn Abdulmelik b. Abdullah, el- 'Akîdetü'n-Nizâmiyye fi'l-Erkâni'l-İslâmiyye, tah. Muhammed Zâhid el-Kevserî, Kahire, $1412 / 1992$. deriyye, 1969.

, eş-Şâmil fí Usûli'd-Dîn, tah. Ali Sami en-Neşşâr ve dğr., İsken, Kitâbu'l-İrşâd ilâ Kavâtı 'il-Edille fì Usûli'l-I' 'tikâd, tah. Ahmed Abdurrahîm es-Sâyih, Kahire, 1430/2009.

Divlekçi, Celalettin, "Kur'an'da Eşanlamlılık (Terâdüf) Olgusu (I)”, SDÜ İlahiyat Fakültesi Dergisi, say1 7, 2000.

Ebû Hanife, el- 'Âlim ve'l-Müte 'allim, tah. Muhammed Zâhid el-Kevserî, y.y., $1368 \mathrm{~h}$.

Ebû Hâtim er-Râzî, Ahmed b. Hamdân, Kitâbu'z-Zîne, tah. Sa 'îd el-Gânimî, Beyrut, 2015.

Ebû Hilâl el-Askerî, el-Furûku'l-Lugaviyye, tah. Muhammed İbrâhîm Selîm, Kahire, t.y.

, Kitâbu's-Sinâ'ateyn: el-Kitâbe ve'ş-Şi ‘r, tah. Ali Muhammed el-Becâvî, Muhammed Ebu'l-Fazl İbrâhîm, 1371/1952.

Ebû Ubeyd, Kâsım b. Sellâm, el-Garîbu'l-Musannef, tah. Muhammed el-Muhtâr el-Ubeydî, 1. bs., Kahire, 1416/1996.

Ebu'l-Bekâ, Eyyûb b. Mûsâ el-Hüseynî el-Kefevî, el-Külliyyât, tah. Adnân Dervîş, Muhammed el-Misrî, 2. bs., Beyrut, 1419/1998.

Enîs, İbrahim, Fi'l-Lehecâti'l- 'Arabiyye, Kahire, 2003.

Eş'arî, Ebu'l-Hasan Ali b. İsmail b. Abdullah, el-ỉbâne 'an Usûli'd-Diyâne, Beyrut, Dâru İbn Zeydûn, t.y.

Ferâhîdî, Halîl b. Ahmed, Kitâbu'l- 'Ayn, tah. Abdulhamîd Hindâvî, 1. bs., Beyrut, Dâru'l-Kütübi'l-İlmiyye, 1424/2003. 
Ferrâ, Ebû Zekeriyyâ Yahyâ b. Ziyâd, Me 'ânî'l-Kur'ân, 3. bs., Beyrut, Âlemü'l-Kütüb, 1403/1983.

Fîrûzâbâdî, Mecdüddîn Muhammed b. Ya'kûb, Besâiru Zevî't-Temyîz fí Letâfi Kitâbi'l-Azîz, tah. Muhammed Ali en-Neccâr, 3. bs., Kahire, 1416/1996.

Gazzâlî, Ebû Hâmid Muhammed b. Muhammed et-Tûsî, el-Maksadu'l-Esnâ fỉ Şerhi Esmâillâhi’l-Hüsnâ, 1. bs., Cidde, Dâru'l-Minhâc, 1439/2018. , el-Mustasfâ min 'İlmi'l-Usûl, tah. Hamza b. Züheyr Hâfız, y.y., t.y. , Mihekkü'n-Nazar, tah. Refîk el'Acem, Beyrut, t.y.

Hafâcî, Muhammed Ali Rızk, 'Ilmu'l-Fesâhati'l-'Arabiyye, Kahire, Dâru'l-Me'ârif, 1982.

Hattâbî, Ebû Süleyman Hamd b. Muhammed, "Beyânu İ'câzi'l-Kur'ân", Selâsü Resâil fí I'câzi'l-Kur'ân, (içinde), tah. Muhammed Halefullah Ahmed, Muhammed Zağlûl Selâm, 3. bs., Kahire, Dâru'l-Me'ârif, t.y.

Heyâcene, Mahmûd Selîm Muhammed, el-1̂zâh fi't-Terâdüf, İrbid, 1437/2016.

İbn Cinnî, Ebu'l-Feth Osman, el-Hasâis, tah. Muhammed Ali en-Neccâr, 3. bs., y.y., el-Hey'etü'l-Misriyyeti'l-Âmme li'l-Kitâb, 1988.

İbn Dürüsteveyh, Ebû Muhammed Abdullah b. Ca'fer, Tashîhu'l-Fasîh ve Şerhihi, tah. Meuhammed Bedevî el-Mahtûn, Kahire, 1425/2004.

İbn Ebi'l-İzz, Ali b. Ali b. Muhammed, Şerhu'l-Akîdeti 't-Tahâviyye, tah. Abdullah Abdulmuhsin et-Türkî, Şuayb el-Arnaût, Beyrut, 1413/1992.

İbn Fâris, Ebu'l-Hüseyn Ahmed b. Fâris b. Zekeriyyâ, es-Sâhibî, tah. es-Seyyid Ahmed Sakr, Kahire, t.y. , Mu'cemu Mekâyîsi'l-Luga, tah. Abdüsselâm Muhammed Hârûn, b.y., Dâru'l-Fikr, t.y.

İbn Fûrek, Muhammed b. el-Hasan, Makâlâtu'ş-Şeyh Ebi'l-Hasan el-Eş 'arî, tah. Ahmed Abdurrahîm es-Sâyih, Kahire, 1425/2005.

İbn Hallikân, Ahmed b. Muhammed b. Ebî Bekr, Vefeyâtu'l-A 'yân, tah. İhsân Abbâs, Beyrut, 1398/1978.

İbn Hazm, Ebû Muhammed Ali b. Ahmed, el-Fasl fi'l-Milel ve'l-Ehvâ' $v e$ 'n-Nihal, tah. Muhammed İbrahim Nasr, Abdurrahman Umeyre, 2. bs., Beyrut, 1416/1996.

İbn Kuteybe, Ebû Muhammed Abdullah b. Müslim, Edebü'l-Kâtib, tah. Ali Fâ‘ûr, y.y., t.y. 
İbn Mâlik et-Tâî, Muhammed b. Abdullah, Kitâbu'l-Elfâzi'l-Muhatelife fi'l-Me 'ânî'l-Mu'telife, tah. Necât Hasan Abdullah Nevlî, Mekke, Câmi'atu Ümmi'l-Kurâ, t.y.

İbn Sîde, Ebu'l-Hasan Ali b. İsmâîl, el-Muhassas, 1. bs., Misır, 1320h.

İbn Tâvûs, Ali b. Mûsâ b. Ca'fer, Sa 'du's-Su 'ûd li'n-Nufûs, tah. Fâris Tebrîzân el-Hassûn, İran, 1379.

İbn Teymiyye, Takiyyüddîn Ahmed b. Abdulhalîm, Mecmû'u'l-Fetevâ, Medine, $1425 / 2004$.

İbnü'l-Hâcib, Ebû Amr Osman b. Ömer b. Ebî Bekr, Müntehâ'l-Vusûl ve'l-Emel fì 'İlmeyi'l-Usûl ve'l-Cedel, 1. bs., Misır, 1326h.

İbnü'l-Hümâm, Kemâlüddîn b. Ebî Şerîf, Kitâbu'l-Müsâmera fî Şerhi'l-Müsâyera, 2. bs., Misır, 1347h.

İbnü'n-Nedîm, Ebu'l-Ferec Muhammed b. İshâk, Kitâbu'l-Fihrist, tah. Eymen Fuâd Seyyid, London, 1430/2009.

Kutrub, Ebû Ali Muhammed b. el-Müstenîr, Kitâbu'l-Ezdâd, tah. Hannâ Haddâd, Riyad, 1405/1984.

Mâtürîdî, Ebû Mansûr Muhammed b. Muhammed, Kitâbu't-Tevhîd, tah. Bekir Topaloğlu, Muhammed Aruçi, Beyrut, Dar Sader, 2010.

Mâtürîdî, Ebû Mansûr Muhammed b. Muhammed, Te'vîlâtu'l-Kur'ân, İstanbul, Dâru'l-Mîzân, 2007.

Mustafavî, Hasan, et-Tahkîk fî Kelimâti'l-Kur'âni'l-Kerîm, 1. bs., Tahran, 1385.

Müberred, Ebu'l-Abbâs b. Yezîd, Mâ İttefeka Lafzuhu ve İhtelefe Ma'nâhu mine'l-Kur'âni'l-Mecîd, tah. Ahmed Muhammed Süleyman Ebû Ra'd, 1. bs., Kuveyt, Vezâret'l-Evkaf ve'ş-Şu'ûnu'l-İslâmiyye, 1409/1988.

Mükerrem, Abdul'âl Sâlim, et-Terâdüffi'l-Hakli'l-Kur'ânî, Kahire, 2009.

Müneccid, Muhammed Nûruddîn, et-Terâdüf fi'l-Kur'âni'l-Kerîm (Beyne'n-Naariyye ve't-Tatbîk), 1. bs., Beyrut, Dımaşk, 1417/1997.

Nesefi, Ebu'l-Mu'în Meymûn, Bahru'l-Kelâm, tah. Veliyyüddîn Muhammed Salih e-Furfûr, 2. bs., y.y., 1421/2000.

bs., Kahire, 1406/1986.

, et-Temhîd li Kavâidi 't-Tevhîd, tah. Habîbullah Hasan Ahmed, 1. , Tabsiratü'l-Edille fí Usûli'd-Dîn, tah. Muhammed el-Enver Hâmid İsâ, 1. bs., Kahire, 2011. 
Oğuz, Orhan, “Kur'ân-1 Kerim'de Terâdüf”, (Yayımlanmamış Doktora Tezi), Bozok Üniversitesi Sosyal Bilimler Enstitüsü, Yozgat, 2016.

Ömer, Ahmed Muhtâr, 'İlmu'd-Dilâle, 5. bs., Kahire, 'Âlemü’l-Kütüb, 1998.

Pezdevî, Ebü'l-Yüsr Muhammed, Usûlu'd-Dîn, tah. Hans Peter Linss, Kahire, 1424/2003.

Raghib, Haidar - Farid, Edi Kurniawan, “et-Tahlîlü'd-Dilâlî 'ani’t-Terdâdüf fi'l-Âyâti'l-Kur'âniyye Sûreti Yûsuf”, An-Nas: Jurnal Humaniora, vol. 2, num. 1, September 2017.

Râgıb el-İsfahânî, Ebu'l-Kâsım el-Hüseyin b. Muhammed, el-Müfredât fî Garîbi'l-Kur'ân, y.y., Mektebetü Nizâr Mustafa el-Bâz, t.y.

Râzî, Fahreddîn Muhammed b. Ömer, el-Mahsûl fì Usûli'l-Fikh, tah. Tâhâ Câbir Feyyâz el-'Alvânî, 2. bs., Beyrut, 1412/1992. ru'l-Fikr, 1401/1981.

, et-Tefsîru'l-Kebîr (Mefâtîhu'l-Gayb), 1. bs., Beyrut, Dâ, Kitâbu'l-Erba 'în fî Usûli'd-Dîn, 1. bs., Haydarabad, 1353h., , Levâmi 'u’l-Beyyinât Şerhu Esmâillâhi Te 'âlâ ve’s-Slfât, Misır, $1323 \mathrm{~h}$.

Recûbî, Muhammed Sâlim, “el-'Arabiyye beyne’t-Terâdüf ve'l-Furûki'l-Lügaviyye”, Mecelletü'l-Buhûsi'l-Akademiyye, say1 6, Misrata, 2016.

Rummânî, Ebu'l-Hasan Ali b. İsâ b. Ali, el-Elfâzu'l-Müterâdifetü'l-Mütekâribetü'l-Ma 'nâ, tah. Fethullah Sâlih Ali el-Misrî, 1. bs., y.y., 1407/1987.

, Tefsîru Ebi'l-Hasan er-Rummânî, (Mevsû 'atu Tefâsiri'l-Mu 'tezile), cem ve tah. Hıdr Muhammed Nebhâ, Lübnan, 2009.

Sâbûnî, Nûreddin, el-Kifâye fi'l-Hidâye, tah. Muhammed Aruçi, Beyrut, Dâru İbn Hazm, 1435/2014.

, Kitâbu'l-Bidâye mine'l-Kifâye fi'l-Hidâye fì Usûl'id-Dîn, tah. Fethullah Huleyf, Misır, 1969.

Seâlibî, Ebû Mansûr Abdulmelik b. Muhammed b. İsmâîl, Fikhu'l-Luğa ve Esrâru'l- 'Arabiyye, tah. Yâsîn el-Eyyûbî, 2. bs., Beyrut, 1420/2000.

Sîbeveyh, Ebû Bişr Amr b. Osmân b. Kanber el-Hârisî, el-Kitâb (Kitâbu Sîbeveyh), tah. Abdüsselâm Muhammed Hârûn, 3. bs., Kahire, 1408/1988.

Subhî es-Sâlih, Dirâsât fí Fıkhi'l-Luğa, Beyrut, 2009. 
Suyûtî, Celâlüddîn, el-Müzhir fì 'Ulûmi'l-Luga ve Envâ 'ihâ, tah. Muhammed Ahmed Câd el-Mevlâ, 4. bs., Kahire, 1958.

Sübkî, Ali b. Abdulkâfî, el-ỉbhâc fi Şerhi'l-Minhâc, tah. Şa ‘bân Muhammed İsmâîl, Kahire, 1401/1981.

Şâyi', Muhammed b. Abdurrahman Sâlih, el-Furûku'l-Lügaviyye ve Eserühâ fî Tefsîri'l-Kur'âni'l-Kerîm, 1. bs., Riyad, 1414/1993.

Şehristânî, Abdülkerîm, Nihâyetü’l-İkdâm fì 'İlmi’l-Kelâm, tah. Alfred Guillaume, London, Oxforf University Press, 1934.

Tehânevî, Muhammed Ali, Keşşâfu Istılâhâti'l-Fünûn ve'l-Ulûm, tah. Refík el-Âcem, Ali Dehrûc, 1. bs., Beyrut, 1996, s. 406

Tûsî, Ebû Ca'fer Muhammed b. Muhammed b. el-Hasan Nasîruddîn, Tecrîdü'l-I' ‘ikâd, tah. Muhammed Cevâd el-Hüseynî el-Celâlî, 1. bs., y.y., 1407h.

Zebîdî, Muhammed b. Muhammed b. Abdurrezzak el-Murtezâ, Tâcu'l- 'Arûs min Cevâhiri'l-Kâmûs, tah. Abdulfettah el-Hulv, Kuveyt, 1406/1986.

Zemahşerî, Ebu'l-Kâsım Cârullah Muhammed b. Ömer b. Ahmed, Esâsü'l-Belâğa, 1. bs., Beyrut, Dâru'l-Kütübi'l-İlmiyye, 1419/1998.

Zerkeşî, Bedrüddîn Muhammed b. Abdullah, el-Bahru'l-Muhît fî̀ Usûli’l-Fıkh, tah. Abdulkâdir Abdullah el-'Ânî, 2. bs., Kuveyt, 1413/1992.

Ziyâdî, Hâkim Mâlik, et-Terâdüffi'l-Luga, Bağdat, 1980.

\section{Araştırmacıların Katkı Oranı}

Araştırmanın her aşamasından yazar sorumludur.

\section{Çatışma Beyanı}

Araştırmada herhangi bir çıkar çatışması bulunmamaktadır. 